\title{
Metallogeny of the Dagangou Au-Ag-Cu-Sb Deposit in the Eastern Kunlun Orogen, NW China: Constraints from Ore-Forming Fluid Geochemistry and S-H-O Isotopes
}

\author{
Liang Li $\mathbb{D},{ }^{1,2}$ Haotian Liu $\left(\mathbb{D},{ }^{3}\right.$ Changbing Wang $\mathbb{D},{ }^{4}$ Fengyue Sun $\mathbb{D}^{5},{ }^{5}$ Kai Zhang $\mathbb{D},{ }^{6}$ \\ Chengcheng You $\left(1,{ }^{7}\right.$ Yonggang Sun $\left(10,{ }^{5}\right.$ and Shucheng Tan $\left(\mathbb{1}^{1}\right.$ \\ ${ }^{1}$ School of Earth Sciences, Yunnan University, Kunming 650500, China \\ ${ }^{2}$ Yunnan Key Laboratory of Statistical Modeling and Data Analysis, Department of Statistics, Yunnan University, Kunming, \\ Yunnan 650500, China \\ ${ }^{3}$ Jilin Institute of Geological Sciences, Changchun 130000, China \\ ${ }^{4}$ No.209 Geological Party, Geological Bureau of Yunnan Nuclear Industry, Kunming 650106, China \\ ${ }^{5}$ College of Earth Sciences, Jilin University, Changchun 130061, China \\ ${ }^{6}$ Xi'an Institute of Geological and Mineral Exploration, Shaanxi Geology and Mineral Bureau, Xi'an 710100, China \\ ${ }^{7}$ No. 1 Geological Survey Institute of Jilin Province, Changchun, Jilin 130031, China \\ Correspondence should be addressed to Shucheng Tan; shchtan@ynu.edu.cn
}

Received 22 April 2021; Revised 16 June 2021; Accepted 23 June 2021; Published 20 July 2021

Academic Editor: Chris Harris

Copyright ( 2021 Liang Li et al. This is an open access article distributed under the Creative Commons Attribution License, which permits unrestricted use, distribution, and reproduction in any medium, provided the original work is properly cited.

\begin{abstract}
A study of ore-forming fluid geochemistry and S-H-O isotopes has been conducted to reveal the metallogeny of the Dagangou $\mathrm{Au}-\mathrm{Ag}-\mathrm{Cu}-\mathrm{Sb}$ deposit, NW China. Three mineralization stages are identified within Dagangou, including ankerite-quartz-pyrite (Ank-Qz-Py), quartz-Au-sulfide (Qz-Au-Sul), and quartz-calcite (Qz-Cal) stages. Four types of primary fluid inclusions (FIs) and various fluid inclusion assemblages (FIAs) are identified by petrographic observations, including pure $\mathrm{CO}_{2}$, $\mathrm{CO}_{2}$-bearing, vapourliquid and halite-bearing FIs, most of which are distributed randomly or along growth zones. Raman spectroscopy suggests that the fluid vapour is mainly $\mathrm{H}_{2} \mathrm{O}$ and $\mathrm{CO}_{2}$ with minor $\mathrm{N}_{2}, \mathrm{CH}_{4}$, and $\mathrm{C}_{2} \mathrm{H}_{6}$. The homogenization temperatures of primary FIs from the Ank-Qz-Py to Qz-Au-Sul to Qz-Cal stages are $208.7-313.4^{\circ} \mathrm{C}, 184.3-251.7^{\circ} \mathrm{C}$, and $167.3-224.2^{\circ} \mathrm{C}$, with salinities of $3.4-13.4$ wt.\%, 5.4-39.5 wt.\% and 4.9-11.4 wt.\% $\mathrm{NaCl}_{\text {equiv. }}$. Sulfide $\mathrm{S}$ isotopes show a predominant source of sedimentary sulfur with minor magmatic sulfur, as evidenced by $\delta^{34} \mathrm{~S}$ values of $-1.4-5.1 \%$. The FI H-O isotopes reveal that the primary fluid was derived from magmatic waters mixed with minor sedimentary water $\left(\delta \mathrm{D}=-90.0\right.$ to $-86.8 \%$, $\delta^{18} \mathrm{O}_{\mathrm{H} 2 \mathrm{O}}=6.7-7.4 \%$ o $)$ and then was significantly diluted by meteoric water in the Qz-Cal stage $\left(\delta \mathrm{D}=-97.2\right.$ to $-95.7 \%$, $\delta^{18} \mathrm{O}_{\mathrm{H} 2 \mathrm{O}}=3.9-4.3 \%$ ). Thus, the ore-forming fluid geochemistry and $\mathrm{S}-\mathrm{H}-\mathrm{O}$ isotopes indicate that fluid boiling occurred in the Qz-Au-Sul stage due to a pressure reduction from $85 \mathrm{MPa}$ to $70 \mathrm{MPa}$, which led to the phase separation of fluid, loss of $\mathrm{CO}_{2}$, increase in residual fluid salinity, and formation of immiscible FIAs and halite-bearing FIs in the Qz-Au-Sul stage. This indicates a system moving away from a primary equilibrium, resulting in the deposition of metallic elements. The Dagangou Au-Ag-Cu-Sb deposit, therefore, is an orogenic gold-polymetallic deposit with a mesozonal depth of $5.9-7.5 \mathrm{~km}$.
\end{abstract}

\section{Introduction}

The Eastern Kunlun Orogen (EKO) in western China hosts significant iron, copper, gold, and polymetallic mineral resources and has been the focus of geological investigations since the 1950s [1]. Since the 1980s, research has focused on the geological setting and mineralizing processes [1-5] related to the deposits in this area and the westward exploration of national prospecting for mineral deposits. This has led to a significant increase in exploration success within the EKO and the discovery of numerous mineral deposits in the area, including the Dachang Au-Sb [6], Wulonggou Au 
[7], Baiganhu W-Sn [8], Galinge Fe [9], Kendekeke Fe-Co(Bi) [10], Akechukesai Ni-Co [11], Xiarihamu Ni-Co- $(\mathrm{Cu})$ [12], Shitoukengde Ni-Co-Cu [13], and Halaguole Ag-Au$\mathrm{Cu}$ deposits, confirming the high prospectivity of the Eastern Kunlun Metallogenic Belt. The integration of geologic surveys, geophysics, geochemistry, and remote sensing has led to the identification of a series of $\mathrm{Au}, \mathrm{Ag}, \mathrm{Cu}, \mathrm{Ni}$, $\mathrm{Co}, \mathrm{Fe}, \mathrm{Pb}, \mathrm{Zn}, \mathrm{Sb}$, and polymetallic mineralized anomalies. Moreover, a number of large- to medium-sized goldpolymetallic deposits have been found, such as the Dachang, Wulonggou, Huanglonggou, Shuizhadonggou, Hongqigou, Yanjingou, Baidungou, Xintuo, Haxiwa, Kaihuangbei, Guoluolongwa, Annage, Walega, Delong, and Asiha deposits [4, $6,14-17]$. These discoveries will promote further research on the formation of gold-polymetallic deposits and metallogenic processes in the EKO.

Studies show that the gold-polymetallic deposits in the EKO are closely related to tectono-hydrothermal activity in metallogenesis, and they are also very important deposit types in the Eastern Kunlun Metallogenic Belt (EKMB), producing most of the gold resources $[14,15,17,18]$. Many studies have been performed on these gold-polymetallic deposits, mainly involving geological characteristics, oreforming fluid characteristics and evolution, ore-forming material sources, metallogenic ages, ore genesis, and metallogeny $[4-6,15,17-22]$. First, researchers have found that the ore-forming fluids of these gold-polymetallic deposits generally have the characteristics of medium to high temperatures and medium to low salinities, with a wide range of variations. The temperature of some deposits in the early mineralization stage can reach $350^{\circ} \mathrm{C}$ or even higher, and the metallogenic temperature of most deposits is between $240^{\circ} \mathrm{C}$ and $340^{\circ} \mathrm{C}$. However, due to the mixing of meteoric water, the temperature in the late mineralization stage often dropped to less than $200^{\circ} \mathrm{C}$ or even less than $150^{\circ} \mathrm{C}$, such as Dachang, Xizangdagou, Kaihuabei, Dongdatan, Guoluolongwa, and Annage deposits [1-6, 15-25]. Meanwhile, fluid inclusions (FIs) with high salinity appear in the ore-forming fluids of some ore deposits, such as Guoluolongwa and Annage deposits, which are up to $22 \%$ or higher $[20,25,26]$. Second, most researchers suggest that the origin of the primary oreforming fluids of these gold-polymetallic deposits is closely related to magmatic water with $\delta \mathrm{D}$ values of -59.6 to $-122 \%$ and $\delta^{18} \mathrm{O}_{\mathrm{H} 2 \mathrm{O}}$ of $0.6-10.7 \%$, which generally belongs to the $\mathrm{NaCl}-\mathrm{H}_{2} \mathrm{O}-\mathrm{CO}_{2}$ system with minor $\mathrm{CH}_{4}$ and $\mathrm{N}_{2}$, but it will be mixed to varying degrees by metamorphic water meteoric water and/or other fluids with evolution [4, 18-25]. Third, a large number of dating results (e.g., zircon fission track or U-Pb dating, hydrothermal mica Ar-Ar dating, and FI Rb-Sr dating) indicate that these gold-polymetallic deposits were mainly formed in the late Indosinian period (197-237 Ma) [21, 27-31], which responded to the strong tectono-magmatism during the geological evolution of the EKO.

The recently discovered Dagangou Au-Ag-Cu-Sb deposit is located between the Middle and South Kunlun Faults [32]. It is part of the Eastern Kunlun Gold-Polymetallic Metallogenic Belt and belongs to a series of Au deposits that exemplify the highly prospective nature of this region. In 2012-
2013, the Xi'an Institute of Geological and Mineral Exploration prescreened this area defined by stream sediment anomalies at a 1: 50,000 scale and identified 3 mineralized alteration zones, 6 ore bodies, and 11 mineralized bodies. Then, the Dagangou Au-Ag-Cu-Sb deposit was prospected as a commercial project by the Qaidam Integrated Institute of Geology and Mineral Resource Exploration, Qinghai Province. Presently, only minimal basic geological research has been undertaken in this area [32], leaving many key issues, including the origin and evolution of the oreforming fluid, the source of ore-forming materials, the processes involved in the formation, and the genesis of the Dagangou deposit, unclear. Here, we combine new FI data with the results of field investigations to determine the nature, composition, and evolution of the ore-forming fluids and discuss the ore genesis and metallogenic processes of the Dagangou Au-Ag-Cu-Sb deposit. We provide new information on the prospects of the Dagangou deposit and the wider Eastern Kunlun Metallogenic Belt for gold-polymetallic mineralization.

\section{Regional Geological Setting}

The Eastern Kunlun Orogen is located in the western segment of the Central Orogenic Belt in China (Figure 1(a)) and is bordered by the Qaidam Massif to the north and the Bayan Har-Songpanganzi Terrane to the south [33]. The EKO trends E-W and is approximately $1500 \mathrm{~km}$ long and 50-200 km wide [34]. Its northern and southern parts differ significantly in terms of basement and geological evolution and are separated by the Middle Kunlun Fault. The granulite facies metamorphic rocks of the Paleoproterozoic Jinshuikou Group constitute the crystalline basement of the northern part, whereas the southern part consists of greenschist facies metamorphic rocks of the Meso-Neoproterozoic Wanbaogou Group [35]. The Wanbaogou Group is mainly composed of basalt, carbonate rock, and clastic rock from bottom to top, in which the basalt has a thickness of $>4000 \mathrm{~m}$ and a pillow structure at the bottom, and is significantly characterized by the features of Oceanic Island Basalt [36]. Meanwhile, carbonate rock formations are carbonate deposits that occur far away from the mainland [37]. Therefore, Sun et al. [34, 35] suggested that the Wanbaogou Group basalt belongs to the Oceanic Basalt Plateau (OBP) based on its distribution characteristics, geochemical characteristics, and geological significance, such as the Ontong Java OBP in the southwestern Pacific, which is currently the largest igneous province on Earth. They further believed that the Wanbaogou basalt has the characteristics of OBP within the oceanic plate, which is related to mantle plume activity in the ocean located far away from the Qaidam Massif in the late Meso-Proterozoic. The Wanbaogou OBP played a significant role in the tectonic evolution and Ni-Cu mineralization of the Eastern Kunlun area in the late Caledonian-early Hercynian. Sun et al. [35] considered the EKO to be a continental marginal Orogen resulting from the Wanbaogou $\mathrm{OBP}$, which converged northward to the southern margin of the Qaidam Massif in the late Silurian and records multiple orogenic stages in the Phanerozoic Eon. 


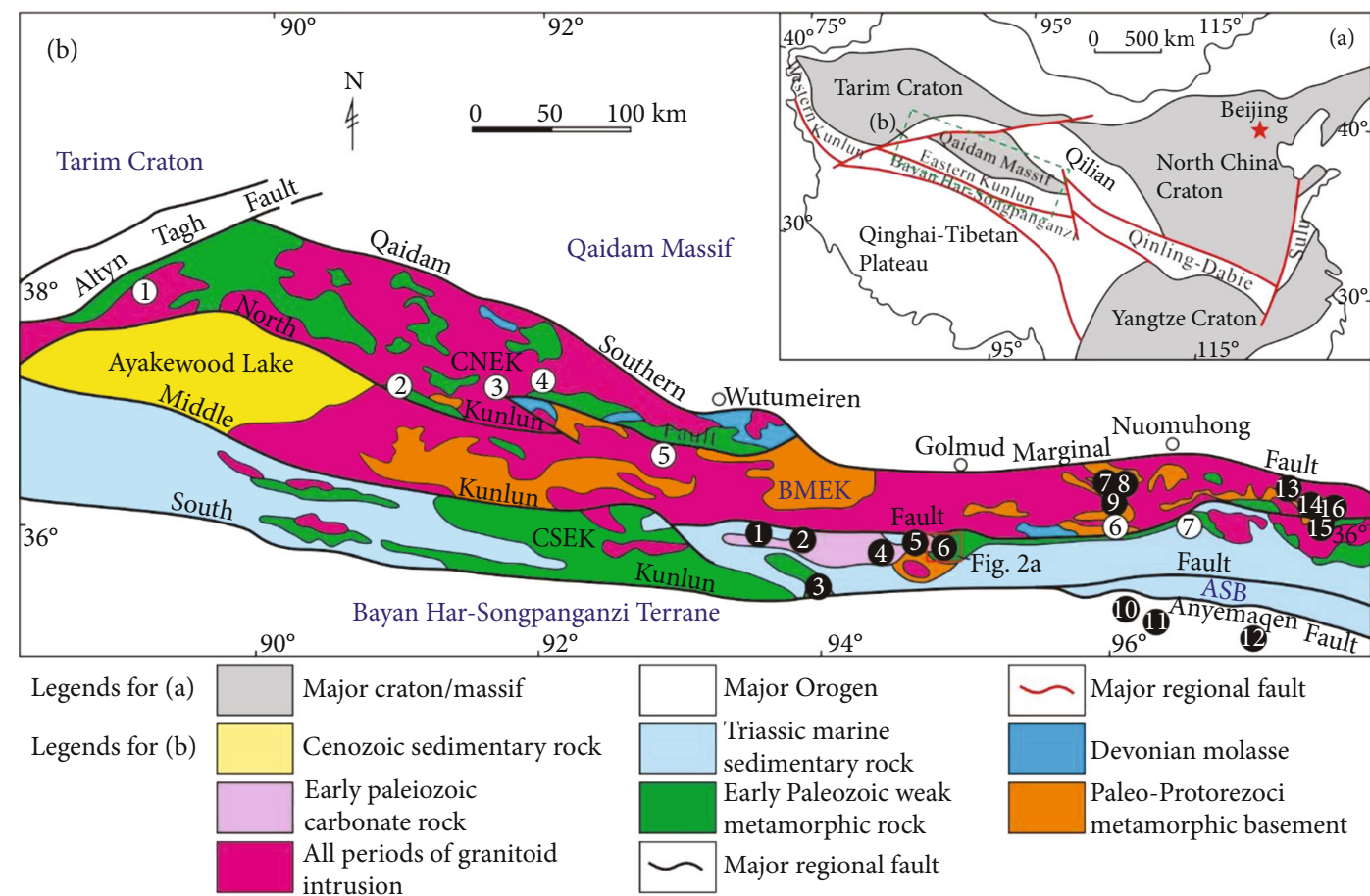

Tectonic units in (b): CNEK: Caledonian back-arc rift belt of North Eastern Kunlun; BMEK: Basement uplift and granite belt of Middle Eastern Kunlun; CSEK: Composite collage belt of South Eastern Kunlun; ASB: Anyemacien Suture Belt
Hydrothermal vein-type gold-polymetal deposits: (1) Dazaohuo
(5) Xiaogangou
6) Dagangou
(12) Cuoni
(7) Wulonggou
(2) Wanbaogou
8 Hongqigou
(14) Asiha
(3)Dongdatam
9 Baidungou
15 Guoluolongwa
(4) Nachitai
(10)iageilongwa

(1) Baiganhu Wu-Sn

Other mineral deposits:

(4) Galinge $\mathrm{Fe}$

(5) Xiarihamu Ni-Co- $(\mathrm{Cu})$
(2) Akechukesai Ni-Co

(6) Shitoukengde $\mathrm{Ni}-\mathrm{Co}-\mathrm{Cu}$
(3) Kendekeke Fe-Co-(Bi)

(7) Halaguole $\mathrm{Ag}-\mathrm{Au}-(\mathrm{Cu})$

Figure 1: (a) Sketch tectonic map of China (modified after Yuan et al. [38]); (b) geological map of the Eastern Kunlun Orogen (modified after $\mathrm{Xu}$ et al. [33]).

The EKO can be divided tectonically into several subparallel E-W-striking belts by the North Kunlun Fault, Middle Kunlun Fault, South Kunlun Fault, and Anyemaqen Fault from north to south. These belts include the Caledonian back-arc rift belt of the Northeastern Kunlun (CNEK), the basement uplift and granite belt of Middle Eastern Kunlun (BMEK), the composite collage belt of Southeastern Kunlun (CSEK), and the Anyemaqen Suture Belt (ASB) (Figure 1(b)) [35].

Precambrian metamorphic rocks and Phanerozoic sedimentary rocks are widespread in the EKO. Paleoproterozoic Jinshuikou Group metamorphic rocks, Middle Permian Ma'erzheng Formation limestones, sandstones and slates, Lower Triassic Bayan Har Group flysch sediments, and Lower Triassic Naocangjiangou Formation foreland basin sedimentary rocks are the main ore-hosting rocks of the hydrothermal deposits in the EKO [2]. The EKO also records intense magmatism that formed numerous suites of basicacid magmatic rocks during various magmatic events, especially within the BMEK $[34,35]$. The CSEK is located between the Middle and South Kunlun Faults and represents an area of folded basement OBP and microcontinental debris basement material that records two main tectonic events: (a) the formation of the Meso-Neoproterozoic Wanbaogou OBP and Caledonian orogenic belt and (b) a Paleo-Tethyan active continental margin between the Late Palaeozoic and Early Mesozoic [35]. The widely exposed Meso-Neoproterozoic
Wanbaogou and Palaeozoic Nachitai Groups record greenschist-facies metamorphism and deformation, and the presence of Late Triassic Babaoshan volcanic rocks and syntectonic emplacement of Indosinian granitoids indicate that the EKO underwent intracontinental tectonism and magmatism [35].

\section{Deposit Geology}

The Dagangou Au-Ag-Cu-Sb deposit is located in the middle of the CSEK, and its ore bodies are hosted by the Middle Permian Ma'erzheng Formation and Early-Middle Triassic Naocangjiangou Formation [39]. The strata are dominated by Ma'erzheng Formation limestones, sandstones, and slates; Naocangjiangou Formation clastic rocks and slates; and Quaternary sediments (Figure 2(a)). Structures in this area mainly include folds and faults, the latter generally trend nearly E-W, and the main mineralization-related structure is the Dagangou ductile shear zone [39]. However, this area contains few magmatic rocks, but small granitic porphyry Indosinian dikes with unclear mineralization relationships are found near the northern part of the Dagangou area.

3.1. Ore Body Characteristics. The Dagangou area is cut by a series of ductile shear zones, which run near the E-W and cross the whole Dagangou area. The deformation, including 


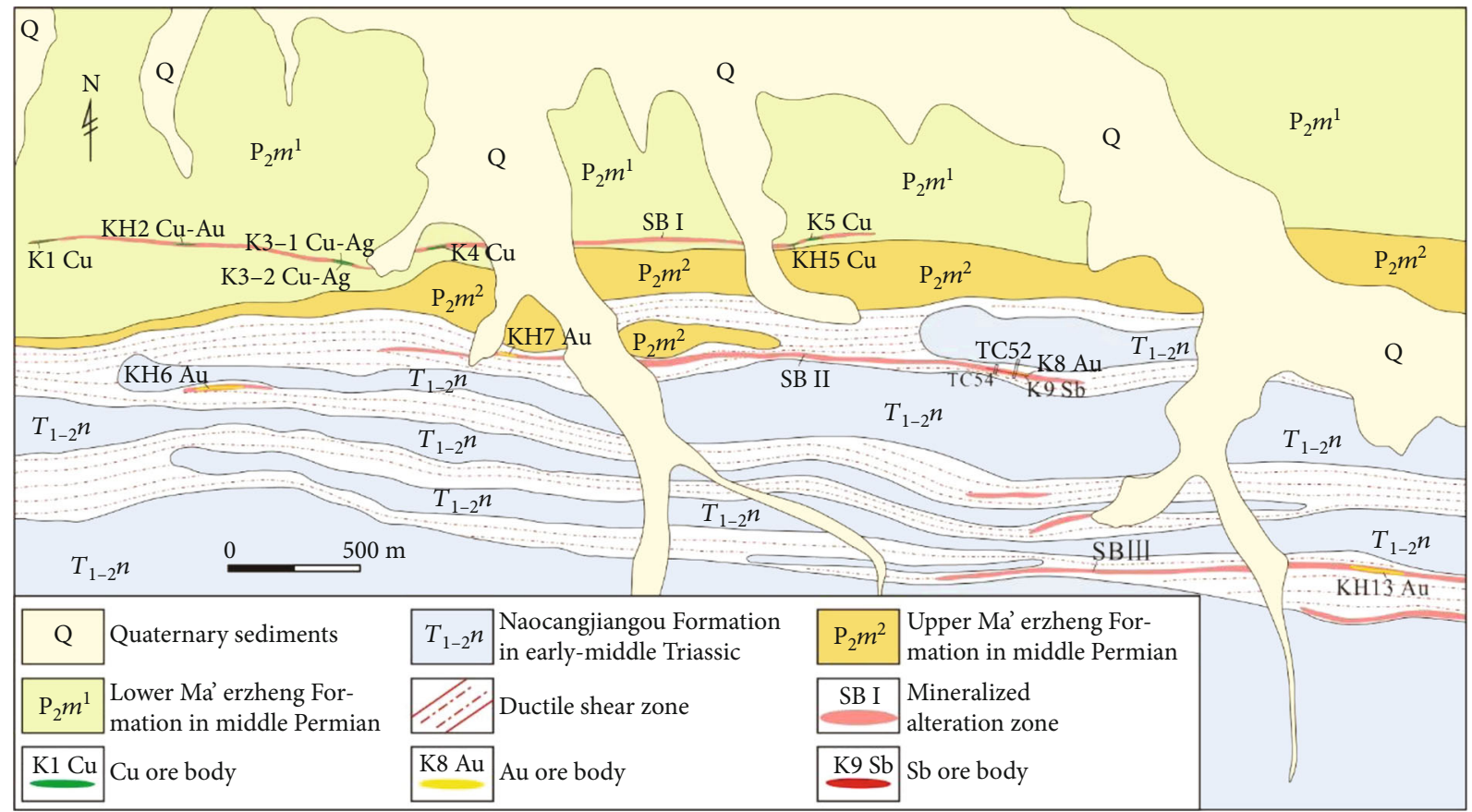

(a)

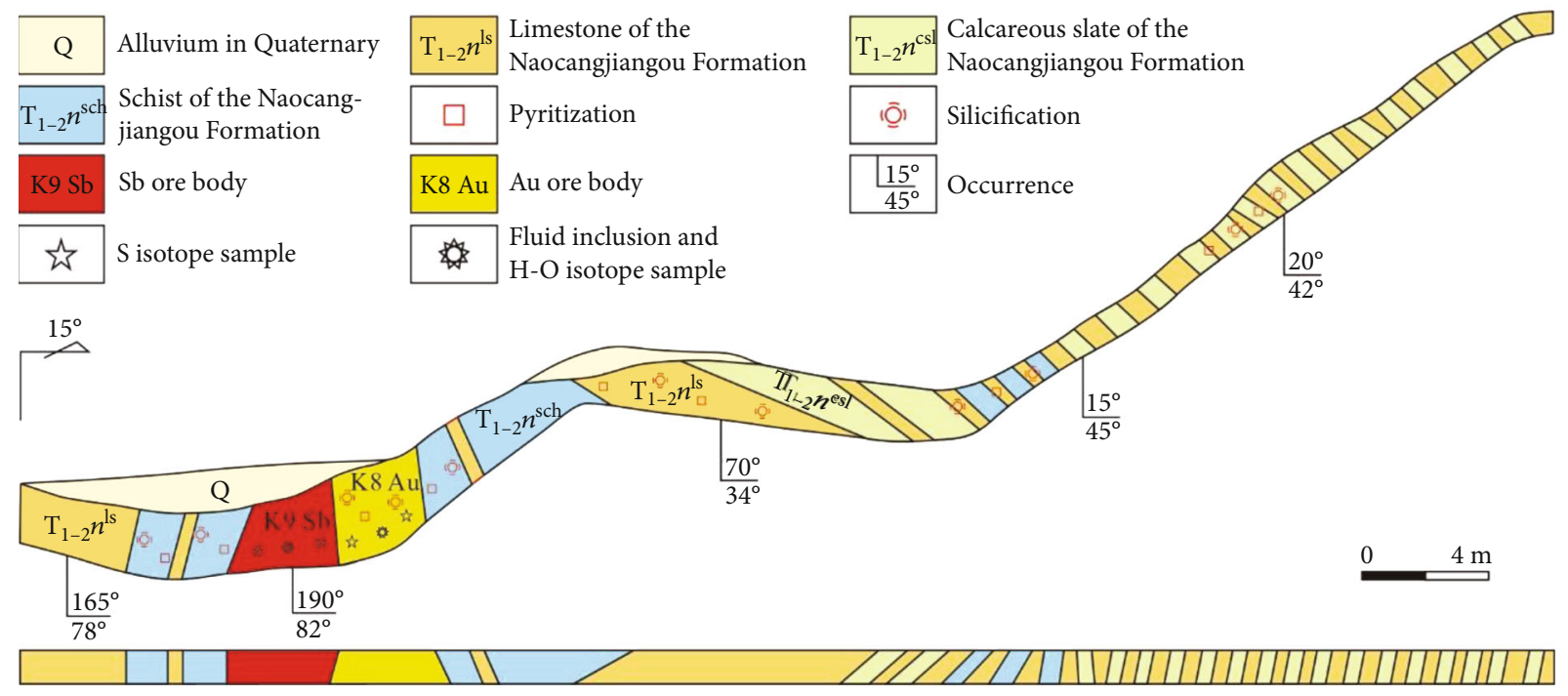

(b)

Figure 2: Geological map of the Dagangou Au-Ag-Cu-Sb deposit (a) and the Trench sketch of TC52 (b) (modified after Zhang et al. [32]).

foliation, S-C fabrics, and rotational augens, of rocks in the shear zones is remarkable. The ductile shear zones are approximately $7-11 \mathrm{~km}$ long from east to the west and $50-600 \mathrm{~m}$ wide, and they are characterized by expansion, contraction, branching, and compounding. Sericitization, silicification, carbonization, and other hydrothermal alterations have occurred in these shear zones and are suitable for metallic element deposition and enrichment. Based on the ore-forming element and mineralization combinations, three main mineralized zones of $\mathrm{Au}-\mathrm{Ag}-\mathrm{Cu}-\mathrm{Sb}$ have been identified in these ductile shear zones (Figure 2(a)) [10]: a Cu-Ag mineralized zone, $\mathrm{Sb}-\mathrm{Au}$ mineralized zone, and Au mineralized zone. According to the ore cut-off grade and production grade, respectively, of $\mathrm{Au}(1 \mathrm{~g} / \mathrm{t} ; 2 \mathrm{~g} / \mathrm{t}), \mathrm{Ag}(50 \mathrm{~g} / \mathrm{t} ; 100 \mathrm{~g} / \mathrm{t}), \mathrm{Cu}(0.3 \% ; 0.5 \%)$, and $\mathrm{Sb}$ $(0.7 \% ; 1.5 \%)$, six ore bodies and ten mineralized bodies have been identified in the mineralized zones (Table 1). The ore grade of the ore body in Dagangou is higher than the production grade, while the ore grade of the mineralized body is between the production grade and cut-off grade. Moreover, the trend of ore bodies is basically consistent with shear zones and is obviously controlled by shear zones. The ore bodies have been investigated mainly by trenching, and the reserve of the Dagangou deposit is difficult to estimate presently due to the low exploration degree [39]. 
TABle 1: Characteristics of the Au-Ag-Cu-Sb ore or mineralized bodies in the Dagangou deposit.

\begin{tabular}{|c|c|c|c|c|}
\hline Mineralized zone & Scale of mineralized zone & Number of ore body & Scale of ore body & $\begin{array}{l}\text { Average } \\
\text { grade }\end{array}$ \\
\hline \multirow{9}{*}{$\begin{array}{l}\text { Cu-Ag-mineralized zone } \\
\text { (SB I) }\end{array}$} & \multirow{9}{*}{$\begin{array}{l}5 \mathrm{~km} \text { long, } 5-20 \mathrm{~m} \text { in thickness, } \\
\text { trend NWW-EW, dip }\left(40^{\circ}-50^{\circ}\right) \\
\text { north }\end{array}$} & $\mathrm{K} 1 \mathrm{Cu}$ ore body & $25 \mathrm{~m}$ long, $0.50 \mathrm{~m}$ in thickness & $\mathrm{Cu} 2.25 \%$ \\
\hline & & KH1 Cu-mineralized body & $30 \mathrm{~m}$ long, $1.11 \mathrm{~m}$ in thickness & $\mathrm{Cu} 0.87 \%$ \\
\hline & & $\mathrm{KH} 2 \mathrm{Cu}$-mineralized body & $15 \mathrm{~m}$ long, $0.07 \mathrm{~m}$ in thickness & $\begin{array}{l}\mathrm{Cu} 0.45 \% \\
\mathrm{Au} 0.75 \mathrm{~g} / \mathrm{t}\end{array}$ \\
\hline & & K3-1 Cu-Ag ore body & $15 \mathrm{~m}$ long, $2.43 \mathrm{~m}$ in thickness & $\begin{array}{l}\mathrm{Cu} 4.72 \% \\
\mathrm{Ag} 289 \mathrm{~g} / \mathrm{t}\end{array}$ \\
\hline & & K3-2 Cu-Ag ore body & $15 \mathrm{~m}$ long, $0.85 \mathrm{~m}$ in thickness & $\begin{array}{l}\mathrm{Cu} 2.12 \% \\
\mathrm{Ag} 141 \mathrm{~g} / \mathrm{t}\end{array}$ \\
\hline & & $\mathrm{K} 4 \mathrm{Cu}$ ore body & $10 \mathrm{~m}$ long, $0.22 \mathrm{~m}$ in thickness & $\mathrm{Cu} 0.57 \%$ \\
\hline & & KH4 Cu-mineralized body & $10 \mathrm{~m}$ long, $1.06 \mathrm{~m}$ in thickness & $\mathrm{Cu} 0.20 \%$ \\
\hline & & $\mathrm{K} 5 \mathrm{Cu}$ ore body & $15 \mathrm{~m}$ long, $1.03 \mathrm{~m}$ in thickness & $\mathrm{Cu} 3.72 \%$ \\
\hline & & KH5 Cu-mineralized body & $12 \mathrm{~m}$ long, $0.18 \mathrm{~m}$ in thickness & $\mathrm{Cu} 0.58 \%$ \\
\hline \multirow{7}{*}{$\begin{array}{l}\text { Au-Sb-mineralized zone } \\
\text { (SB II) }\end{array}$} & \multirow{7}{*}{$\begin{array}{c}3.5 \mathrm{~km} \text { long, } 3-16 \mathrm{~m} \text { in thickness, } \\
\text { trend NWW }\end{array}$} & KH6 Au-mineralized body & $80 \mathrm{~m}$ long, $1.27 \mathrm{~m}$ in thickness & $\mathrm{Au} 0.52 \mathrm{~g} / \mathrm{t}$ \\
\hline & & KH7 Au-mineralized body & $\begin{array}{c}100 \mathrm{~m} \text { long, } 0.80 \mathrm{~m} \text { in } \\
\text { thickness }\end{array}$ & $\mathrm{Au} 0.60 \mathrm{~g} / \mathrm{t}$ \\
\hline & & K8 Au ore body & $50 \mathrm{~m}$ long, $1.45 \mathrm{~m}$ in thickness & $\mathrm{Au} 2.48 \mathrm{~g} / \mathrm{t}$ \\
\hline & & K9 Sb ore body & $\begin{array}{c}120 \mathrm{~m} \text { long, } 2.80 \mathrm{~m} \text { in } \\
\text { thickness }\end{array}$ & $\begin{array}{l}\text { Sb } 3.23 \% \\
\mathrm{Au} 0.48 \mathrm{~g} / \mathrm{t}\end{array}$ \\
\hline & & $\begin{array}{l}\text { KH10 Au-mineralized } \\
\text { body }\end{array}$ & $\begin{array}{c}120 \mathrm{~m} \text { long, } 2.03 \mathrm{~m} \text { in } \\
\text { thickness }\end{array}$ & $\mathrm{Au} 0.83 \mathrm{~g} / \mathrm{t}$ \\
\hline & & $\begin{array}{l}\text { KH11 Au-mineralized } \\
\text { body }\end{array}$ & $\begin{array}{c}120 \mathrm{~m} \text { long, } 1.36 \mathrm{~m} \text { in } \\
\text { thickness }\end{array}$ & $\mathrm{Au} 0.64 \mathrm{~g} / \mathrm{t}$ \\
\hline & & $\begin{array}{l}\text { KH12 Sb-mineralized } \\
\text { body }\end{array}$ & $\begin{array}{c}120 \mathrm{~m} \text { long, } 0.81 \mathrm{~m} \text { in } \\
\text { thickness }\end{array}$ & Sb $1.10 \%$ \\
\hline $\begin{array}{l}\text { Au-mineralized zone } \\
\text { (SB III) }\end{array}$ & $\begin{array}{c}3 \mathrm{~km} \text { long, } 20 \mathrm{~m} \text { in thickness, } \\
\text { trend EW }\end{array}$ & $\begin{array}{l}\text { KH13 Au-mineralized } \\
\text { body }\end{array}$ & $50 \mathrm{~m}$ long, $1.50 \mathrm{~m}$ in thickness & $\mathrm{Au} 0.57 \mathrm{~g} / \mathrm{t}$ \\
\hline
\end{tabular}

(i) Cu-Ag mineralized zone (SB I): SB I is hosted in the Ma'erzheng Formation feldspar lithic sandstone and mainly in copper and silver mineralization. It is approximately $5 \mathrm{~km}$ long and $5-20 \mathrm{~m}$ wide, trends nearly E-W, and is basically consistent with the stratum trending northward at $40^{\circ}-50^{\circ}$. The rocks are characterized by sericitization, carbonization, and silicification. Three $\mathrm{Cu}$ ore bodies, two $\mathrm{Cu}-\mathrm{Ag}$ ore bodies, and four $\mathrm{Cu}-\mathrm{Au})$-mineralized bodies have been identified in SB I (Table 1).

(a) $\mathrm{K} 1 \mathrm{Cu}$ ore body: $\mathrm{K} 1$ is approximately $25 \mathrm{~m}$ long and $0.5 \mathrm{~m}$ wide, dips to the north at $50^{\circ}-60^{\circ}$, and has the same shape as the shear zone. The ore is mainly composed of hydrothermal chalcocite and quartz veins with a $\mathrm{Cu}$ grade of $2.25 \%$. The ore minerals are mainly chalcocite, followed by chalcopyrite and malachite, which occur in the fissures of quartz veins, but the wall rock has weak mineralization.

(b) K3-1 Cu-Ag ore body: K3-1 is approximately $15 \mathrm{~m}$ long and $2.5 \mathrm{~m}$ wide, is hosted in the Ma'erzheng Formation feldspar lithic sandstone, runs nearly E-W, and dips to the south at $50^{\circ}-60^{\circ}$. It contains $4.72 \%$
$\mathrm{Cu}$ (the highest content is $14.71 \%$ ), $289 \mathrm{~g} / \mathrm{t} \mathrm{Ag}$ (Table 1), and chalcocite, argentite, and chalcopyrite.

The rest of the $\mathrm{Cu}-(\mathrm{Au})-(\mathrm{Ag})$ ore/mineralized bodies in SB I have lenticular, banded, and vein-like geological features. They have the same shape as the shear zone, showing the characteristics of structural ore control. Among them, the $\mathrm{K} 4 \mathrm{Cu}, \mathrm{K} 5 \mathrm{Cu}$, and $\mathrm{K} 3-2 \mathrm{Cu}-\mathrm{Ag}$ ore bodies contain average $\mathrm{Cu}$ grades of $0.57 \%, 3.72 \%$ and $2.12 \%$, respectively, with an average $\mathrm{Ag}$ grade of $141 \mathrm{~g} / \mathrm{t}$ for K3-2 (Table 1).

(ii) Au-Sb mineralized zone (SB II): SB II is hosted in the Lower-Middle Triassic Naocangjiangou Formation schist, calcareous slate, and limestone and mainly in gold and antimony mineralization. It is approximately $3.5 \mathrm{~km}$ long and 3-6 $\mathrm{m}$ wide, runs nearly E-W, and dips to the south at $45^{\circ}-55^{\circ}$. The rocks in SB II are characterized by strong hydrothermal alteration, including sericitization, calcitization, and silicification. One Au ore body, one $\mathrm{Sb}$ ore body, and five $\mathrm{Au}-(\mathrm{Sb})$-mineralized bodies have been identified in this zone (Table 1).

(a) K8 Au ore body: K8 is approximately $50 \mathrm{~m}$ long and $1.45 \mathrm{~m}$ wide, and its Au grade is $2.48 \mathrm{~g} / \mathrm{t}$ with a certain 
amount of Sb. It is lenticular in the ductile shear zone, in which the rocks are fragmented and foliated. This ore body is close to the $\mathrm{K} 9 \mathrm{Sb}$ ore body, and they have the same occurrence of dipping south at approximately $80^{\circ}$ (Figure 2(b)). In K8, hydrothermal alterations, including sericitization, carbonization, and silicification, are intense, and pyrite is the common sulfide and main gold-bearing mineral.

(b) $\mathrm{K} 9 \mathrm{Sb}$ ore body: the $\mathrm{K} 9 \mathrm{Sb}$ ore body is close to $\mathrm{K} 8$, and they both dip south at approximately $80^{\circ}$ (Figure 2(b)). K9 is $120 \mathrm{~m}$ long and $2.80 \mathrm{~m}$ wide and controlled by an E-W-directed fault. The ores are mainly composed of stibnite (30-60\%) and gangue minerals $(40-70 \%)$; stibnite is the most important sulfide. The altered schist- and calcareous slate-type ores comprise the main ore, containing average $\mathrm{Sb}$ and $\mathrm{Au}$ grades of $3.23 \%$ and $0.48 \mathrm{~g} / \mathrm{t}$, respectively. Many ore samples were collected from the $\mathrm{K} 8$ and $\mathrm{K} 9$ ore bodies to perform FI microthermometry and H-O-S isotope analysis (Figure 2(b)).

(iii) Au-mineralized zone (SB III): SB III is located in the southern Dagangou area and is hosted in the Naocangjiangou Formation schist, calcareous slate, and limestone. It is approximately $3 \mathrm{~km}$ long and $20 \mathrm{~m}$ wide, runs nearly E-W, and dips to the south at $40^{\circ}-50^{\circ}$. The rocks in SB III are heavily altered, including by sericitization, carbonization, and silicification. The KH13 Au-mineralized body identified in this zone is approximately $50 \mathrm{~m}$ long and $1.5 \mathrm{~m}$ wide and is lenticular and veined in the EW ductile shear zone. It is hosted in the Naocangjiangou Formation, trends E-W, dips to the south at $50^{\circ}$, and is controlled by the fault in this zone. In KH13, the hydrothermal alterations, including sericitization, carbonization, and silicification, are remarkable. Pyrite is the common sulfide that contains $0.57 \mathrm{~g} / \mathrm{t} \mathrm{Au}$.

3.2. Ore Characteristics. The metallic minerals are mainly chalcocite, pyrite, stibnite, and chalcopyrite (Figure 3), followed by argentite, galena, sphalerite, malachite, native gold, and azurite, while the gangue minerals mainly include quartz, feldspar, calcite, ankerite, sericite, calcite, and chlorite.

The Dagangou deposit has two main types of ore: primary sulfide ore and oxidized ore. The primary sulfide $\mathrm{Cu}-(\mathrm{Ag})$ ore is mainly composed of chalcocite, pyrite, and chalcopyrite, which account for $10-50 \%$, while gangue minerals account for $50-90 \%$. Chalcocite is the most important $\mathrm{Cu}$ mineral, with minor chalcopyrite, azurite, and malachite, and chalcocite contains a small amount of Ag. Chalcocite is generally present as granular aggregates between 0.5 and $1.0 \mathrm{~mm}$. Chalcopyrite is a granular aggregate with a grain size of $0.10-0.15 \mathrm{~mm}$, is distributed in quartz gaps in the form of stripes and microveins, and is metasomatized by chalcocite (Figure 3(b)). Some chalcocites fill in between ankerite and quartz locally (Figure 3(a)), indicating that ankerite crystallized earlier than chalcocite. The copper sulfides (e.g., chalco- pyrite and chalcocite) are readily oxidized to azurite and malachite, forming oxidized $\mathrm{Cu}$ ore. $\mathrm{Cu}-(\mathrm{Ag})$ ores show mainly automorphic, hypautomorphic, and xenomorphic granular textures; intersertal and metasomatic textures; and massive, vein, and disseminated structures.

The primary $\mathrm{Sb}-\mathrm{Au}$ sulfide ore is mainly composed of stibnite, pyrite, and chalcopyrite, which account for $30-60 \%$, while gangue minerals account for $40-70 \%$ (e.g., quartz, feldspar ankerite, sericite, and calcite). The Sb ore is composed of stibnite with an abundance of approximately $30-60 \%$ and gangue minerals with abundances of $40-70 \%$, while the Au ore is composed of sulfide with an abundance of approximately $1-3 \%$ and gangue minerals with abundances of $97-99 \%$. Stibnite is greyish white with highly grey blue heterogeneity (Figure 3(f)) and hypautomorphic with lath, strip, and granular shapes and ranges from 0.5 to $2.0 \mathrm{~mm}$, and most grains are distributed unevenly in lumps and veins. Native gold, which is distributed in gangue minerals and pyrite, is the main Au-bearing mineral in the Au ore. It is golden in colour and low in hardness and is classified as microgold with a particle size of $0.001-0.020 \mathrm{~mm}$ [10]. The ore and gangue minerals mainly show automorphic, hypautomorphic, and xenomorphic granular textures and intersertal and metasomatic textures between them. The Sb-Au ores show massive, vein, crumby, and disseminated structures (Figure 3).

3.3. Alteration and Mineralization Stages. Hydrothermal alteration is widespread in the Dagangou deposit, with the most intensive alteration occurring in and around the mineralized $\mathrm{Au}-\mathrm{Ag}-\mathrm{Cu}-\mathrm{Sb}$ veins. The key alteration assemblages mainly include ankeritization (Figure 3(a)), silicification (Figures 3(a), 3(c), and 3(f)), chloritization, sericitization, calcitization, and kaolinitization. The alteration of the surrounding rock in each alteration zone is centred on the ore body with a zoning of outward weakening, and the distribution direction is basically the same as that of the ore-bearing faults. The alterations from the centre to the wall rock are generally ankeritization, silicification, sericitization, kaolinitization, chloritization, and calcitization (Figure 4).

The Dagangou deposit consists of $\mathrm{Cu}-(\mathrm{Ag}), \mathrm{Sb}$, and $\mathrm{Au}$ ore bodies, among which $\mathrm{Au}$ and $\mathrm{Sb}$ mineralization is closely related and often occurs in the same ore body. The mineralization in the Dagangou area shows zoned characteristics of $\mathrm{Sb}-\mathrm{Au}$ in the middle of the deposit, $\mathrm{Cu}-\mathrm{Ag}$ in the northern part of the deposit, and $\mathrm{Au}$ in the southern part of the deposit. Moreover, these mineralizations have similar altered features: (i) they are obviously controlled by the same hydrothermal field, but differences in the surrounding rocks lead to slight differences in these minerals; (ii) the ore bodies are controlled by nearly E-W-trending faults; and (iii) the alteration of surrounding rock in each alteration zone is centred on ore bodies with outwardly weakening zoning, and the distribution direction is basically the same as that of the orebearing faults.

Among the alterations discussed above, silicification is the most widespread and predominant; silicification constitutes the main part of the quartz vein-type ore body and coexists with minor early precipitated ankerite and late 


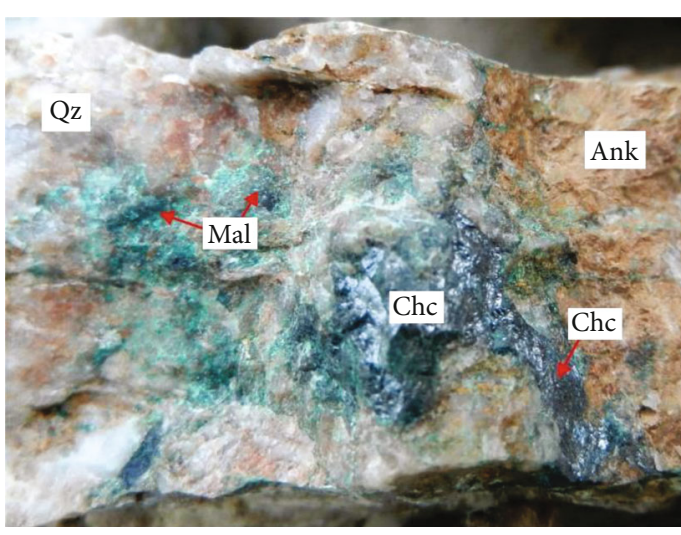

(a)

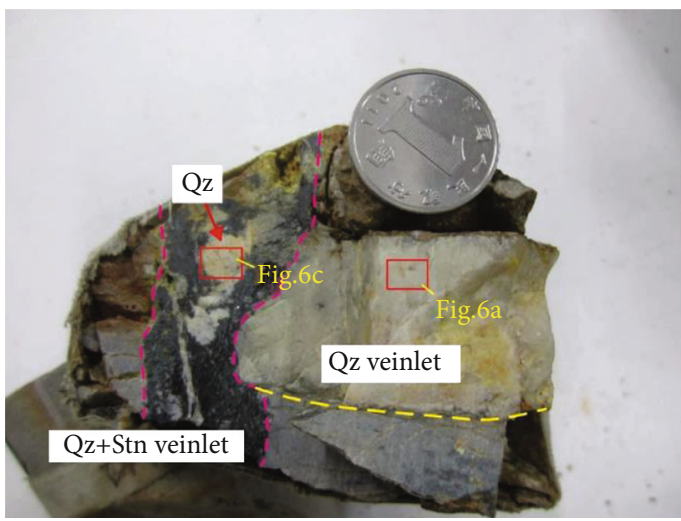

(c)

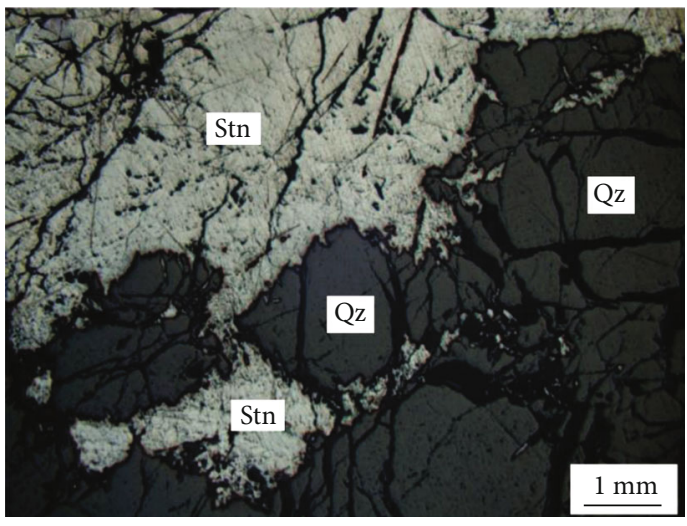

(e)

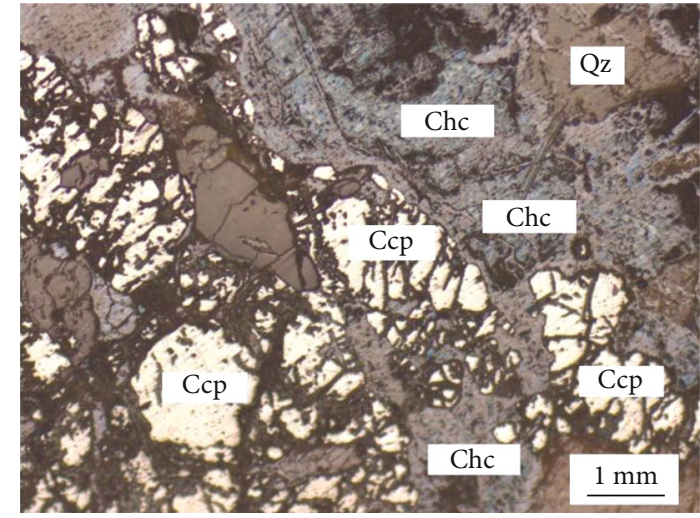

(b)

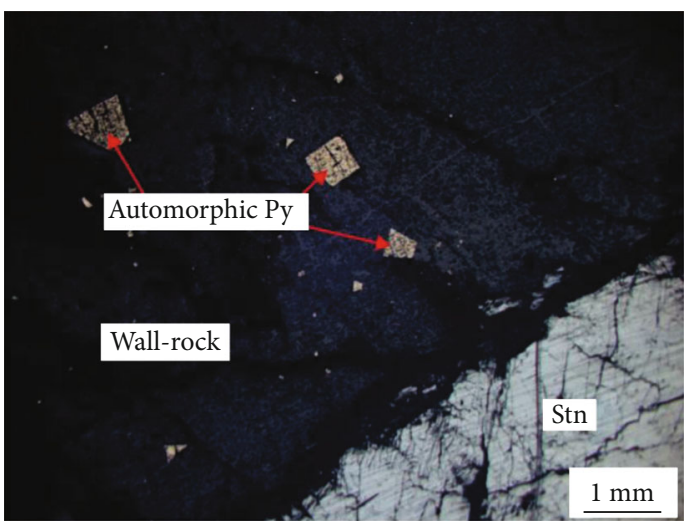

(d)

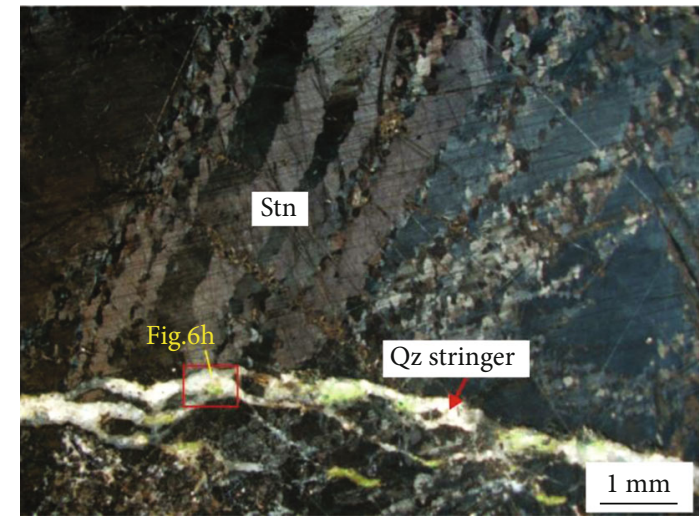

(f)

Figure 3: Representative photos of the hand specimen and micrographs of ores in the Dagangou Au-Ag-Cu-Sb deposit. (a) The quartz-veintype $\mathrm{Cu}$ ore from K3-1 Cu-Ag ore body. The xenomorphic chalcocites filled in the interspace between ankerite and quartz. (b) The chalcopyrite is filled between quartz grains, and chalcocite is metasomatized along the chalcopyrite fissure or interior (plane-polarized light). (c) The stibnite-quartz vein cuts the earlier quartz vein, and sulfides are mainly stibnite with a small amount of pyrite and chalcopyrite. (d) The automorphic pyrite disseminate in the silicified rocks with clear borders (plane-polarized light), and they contain little gold. (e) The xenomorphic stibnite surround the automorphic quartz, indicating the quartz crystallized earlier than stibnite. (f) The quartz stringer crosscuts the earlier stibnite, and the polysynthetic twins of stibnite are remarkable (crossed polarized light). Ank: ankerite; Ccp: chalcopyrite; Cct: chalcocite; Mlc: malachite; Py: pyrite; Qz: quartz; Stb: stibnite. The abbreviation for minerals is cited from Whitney and Evans [40].

carbonate (Figure 4). The Au-Ag-Cu-Sb mineralizations are associated with silicification in the middle stage (Figures 3(a) and 3(e)), and these sulfides coexist with each other, forming different kinds of ores. Quartz veins are commonly interspersed with stibnite-quartz veins (Figure 3(c)), and fine ore-barren quartz veins cut the stibnite (Figure 3(f)). Sericite alteration has a close relationship with silicification in the altered rock $\mathrm{Sb}-(\mathrm{Au})$ ore body, with a significant combination of alteration and $\mathrm{Sb}-\mathrm{Au}$ mineralization. The final stage of hydrothermal alteration is calcitization and 


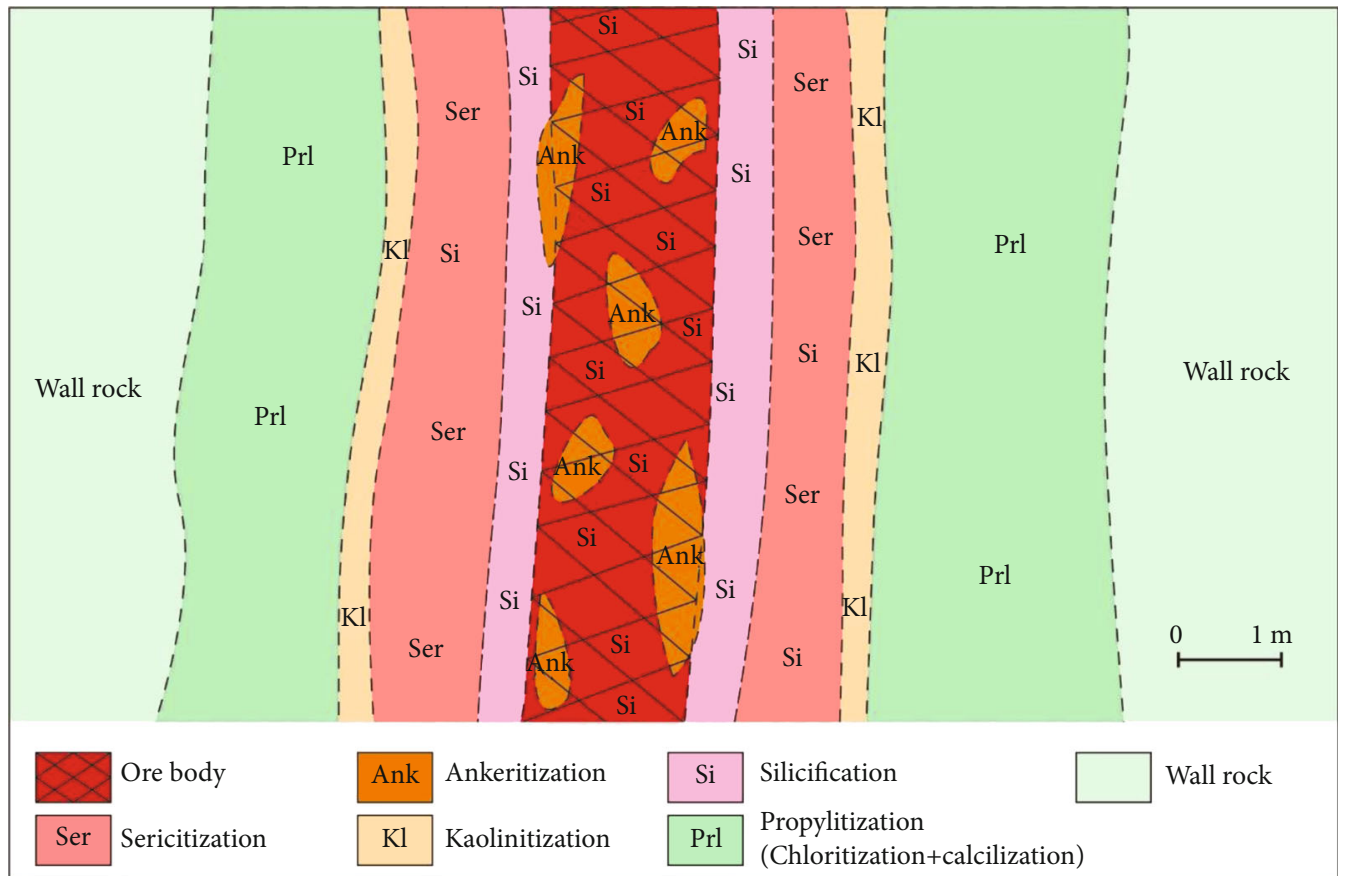

FIgURE 4: Schematic diagram of the hydrothermal alteration zoning within the Dagangou Au-Ag-Cu-Sb deposit.

silicification, which generally occurs on the periphery of the alteration zone (Figure 4) and overprints all the previous alteration types that coexist with minor pyrite.

In conclusion, crosscutting relationships, ore fabrics, and the paragenesis of minerals in Dagangou enable the identification of hydrothermal and supergene periods, with the former being divided into three distinct mineralization stages as follows (Figure 5). The three mineralized zones and the ore or mineralization bodies therein have similar alterations and zoning, and their alterations can also generally be divided into the following three stages.

(i) Ankerite-quartz-pyrite stage (Ank-Qz-Py stage): during this stage, idiomorphic ankerite (Figure 3(a)), feldspar, white-grey quartz veins (Figure 3(c)), and minor euhedral-subhedral pyrite formed (Figure 3(d)). The ankerites are always surrounded by late-stage quartz, and interspaces between ankerite and quartz in this stage are often filled by xenomorphic chalcocites (Figure 3(a)). Moreover, a few idiomorphic pyrites are disseminated in the silicified rocks (Figure 3(d)), whereas little chalcocite, gold, and stibnite precipitated in this stage.

(ii) Quartz-gold-polymetallic sulfide stage (Qz-Au-Sul stage): this stage was characterized by precipitation of large amounts of sulfides, such as chalcocite, stibnite, pyrite, chalcopyrite, and minor sphalerite, representing the main stage of mineralization. Some hypautomorphic-xenomorphic pyrites may be Aubearing minerals containing notable gold [10]. Mineralization is present in massive sulfide, vein, lumpy, and fine-grained disseminated forms and likely represents the main stage of $\mathrm{Au}$ mineralization associated with silicification. Chalcopyrite is generally filled in between the quartz grains, and chalcocite is evident along chalcopyrite fissures or the interior (Figure 3(b)). Stibnite-quartz veins in this stage commonly cut the quartz veins in the AnkQz-Py stage (Figure 3(c)).

(iii) Quartz-calcite stage (Qz-Cal stage): this stage is mainly represented by quartz and calcite with minor pyrite, chalcocite, gold, and stibnite. Veins of finegrained ore-barren quartz that formed during this stage are interspersed with stibnite in the $\mathrm{Qz}-\mathrm{Au}-$ Sul stage (Figure 3(f)).

In the supergene period, azurite, malachite, and limonite are formed by the oxidation of primary sulfides, such as chalcocite, chalcopyrite, and pyrite (Figure 5). Remarkably, some xenomorphic malachites fill in the interspace between ankerite and quartz locally (Figure 3(a)). However, secondary minerals (e.g., azurite, malachite, and limonite) are not a major part of mineral resources in the Dagangou deposit.

\section{Fluid Inclusion Petrography}

Hydrothermal quartz samples from each mineralization stage (Figure 5) were collected from the SB I- and SB IImineralized zones (Figure 2(b)) and were used for systematic petrographic and microthermometric analysis of primary FIs. The quartz samples in the Ank-Qz-Py and Qz-Cal stages are often pure (Figures 3(c) and 3(f)) with small pyrites, while the quartz in the Qz-Au-Sul stage generally coexists with sulfides, such as chalcocite, chalcopyrite, and stibnite (Figures 3(a)-3(c) and 3(e)). 


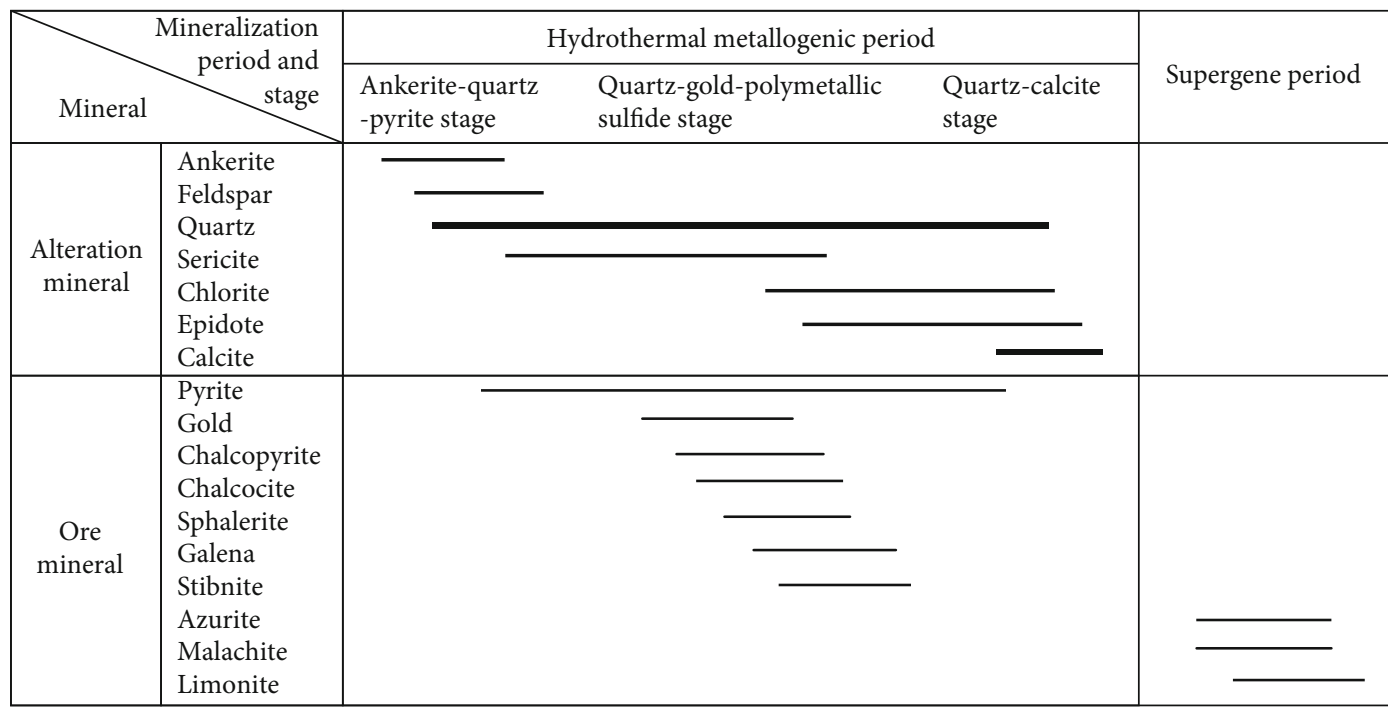

Figure 5: Paragenetic sequence within differing mineralization stages present within the Dagangou Au-Ag-Cu-Sb deposit.

FIs were examined in eight samples from three paragenetic mineralization stages. Abundant FIs in quartz crystals can be classified into two genetic types: primary FIs and secondary FIs. The primary FIs are generally distributed randomly or along growth zones (Figures $6(\mathrm{a})-6(\mathrm{~h})$ ), whereas the secondary FIs with smaller volumes are distributed along quartz fissures (Figure 6(i)). The FIs analysed in this paper are all primary FIs. Based on the phases, composition, degree of filling, and relationship of fluids at room temperature, four distinct FI types are recognized in the three mineralization stages of the Dagangou Au-Ag-Cu-Sb deposit as follows:

(i) Pure $\mathrm{CO}_{2}$ fluid inclusion (type I): pure $\mathrm{CO}_{2}$ FIs are either biphase $L_{\mathrm{CO} 2}$ and $V_{\mathrm{CO} 2}$ FIs or monophase $L_{\mathrm{CO} 2}$ FIs at room temperature; they mainly formed in the Ank-Qz-Py and Qz-Au-Sul stages and have $\mathrm{CO}_{2}$ vapour phase $\left(V_{\mathrm{CO} 2}\right)$ proportions of $10-70 \%$ (generally $30-50 \%$ ). Type I FIs are oval, elongate, and irregularly shaped, $4-20 \mu \mathrm{m}$ in size (generally 8-12 $\mu \mathrm{m}$ ) (Figures 6(a), 6(c), and 6(d)), and homogenize to the vapour phase upon heating.

(ii) $\mathrm{CO}_{2}$-bearing triphase fluid inclusion (type II): $\mathrm{CO}_{2}-$ bearing triphase FIs comprise three phases at room temperature: liquid phase $\mathrm{CO}_{2}\left(L_{\mathrm{CO} 2}\right)$, vapour phase $\mathrm{CO}_{2}\left(V_{\mathrm{CO} 2}\right)$, and saline solutions $\left(L_{\mathrm{H} 2 \mathrm{O}}\right)$. This type of FI is more common in the Ank-Qz-Py and QzAu-Sul stages than in the Qz-Cal stage. These FIs are oval, elongate, irregularly shaped, $3-20 \mu \mathrm{m}$ in size (generally $6-12 \mu \mathrm{m}$ ), and the $\mathrm{CO}_{2}$ phase occupies $25-90 \%$ of the total volume (generally $40-$ $60 \%$ ) with vapour $\mathrm{CO}_{2}$ occupying $30-50 \%$ of the total $\mathrm{CO}_{2}$ phase (Figures 6(a) and 6(d)). Type II FIs generally homogenize to the liquid phase upon heating.

(iii) Vapour-liquid biphase fluid inclusion (type III): type III FIs contain two phases, saline solutions $\left(L_{\mathrm{H} 2 \mathrm{O}}\right)$ and vapour bubbles $\left(V_{\mathrm{H}_{2} \mathrm{O}}\right)$, at room temperature and are present in all three mineralization stages (Figures 3(c) and 3(e)-3(f)). These FIs are either oval, elongate, or irregular in shape, with sizes of 4-20 $\mu \mathrm{m}$ (generally $8-15 \mu \mathrm{m}$ ) and vapour/liquid ratios of $10-70 \%$ (generally $20-40 \%$ ) (Figure 6); these FIs generally homogenize to the liquid phase upon heating.

(iv) Halite-bearing triphase fluid inclusion (type IV): some mineral-bearing triphase FIs are present in the Qz-Au-Sul stage quartz. The daughter minerals in type IV FIs are subcubic, crystalline, and colourless or white, indicating that they are likely halite. This type of inclusion commonly contains halite minerals $\left(S_{\text {halite }}\right)$, saline solutions $\left(L_{\mathrm{H} 2 \mathrm{O}}\right)$, and bubbles $\left(V_{\mathrm{H} 2 \mathrm{O}}\right)$ at room temperature (Figure 6(c)). These FIs are elliptical or irregularly shaped, with sizes of $10-20 \mu \mathrm{m}$ and vapour/liquid ratios of $30-$ $50 \%$. The vapour-liquid phase is first homogenized to the liquid phase during heating, and as the temperature continues to rise, the halite minerals dissolve and eventually homogenize to the liquid phase.

Groups of individual FIs in a particular growth zone of the host mineral or in the same pseudosecondary trails are considered a fluid inclusion assemblage (FIA) [41, 42]. Where growth zones and pseudosecondary trails are absent, FIs that are distributed randomly or in a cluster with similar phase ratios and microthermometric measurements are also treated as an FIA in this study (Figures 6(a), 6(c), and 6(f)) [43]. Therefore, a total of 15 groups of FIAs were recognized in this study, and they usually contain various types of FIs. FIs are abundant in quartz within the Dagangou deposit, but the types of FIs contained in each mineralization stage are quite different. The FIs in Ank-Qz-Py stage quartz are mainly type I, II, and III FIs, which are further classified into 

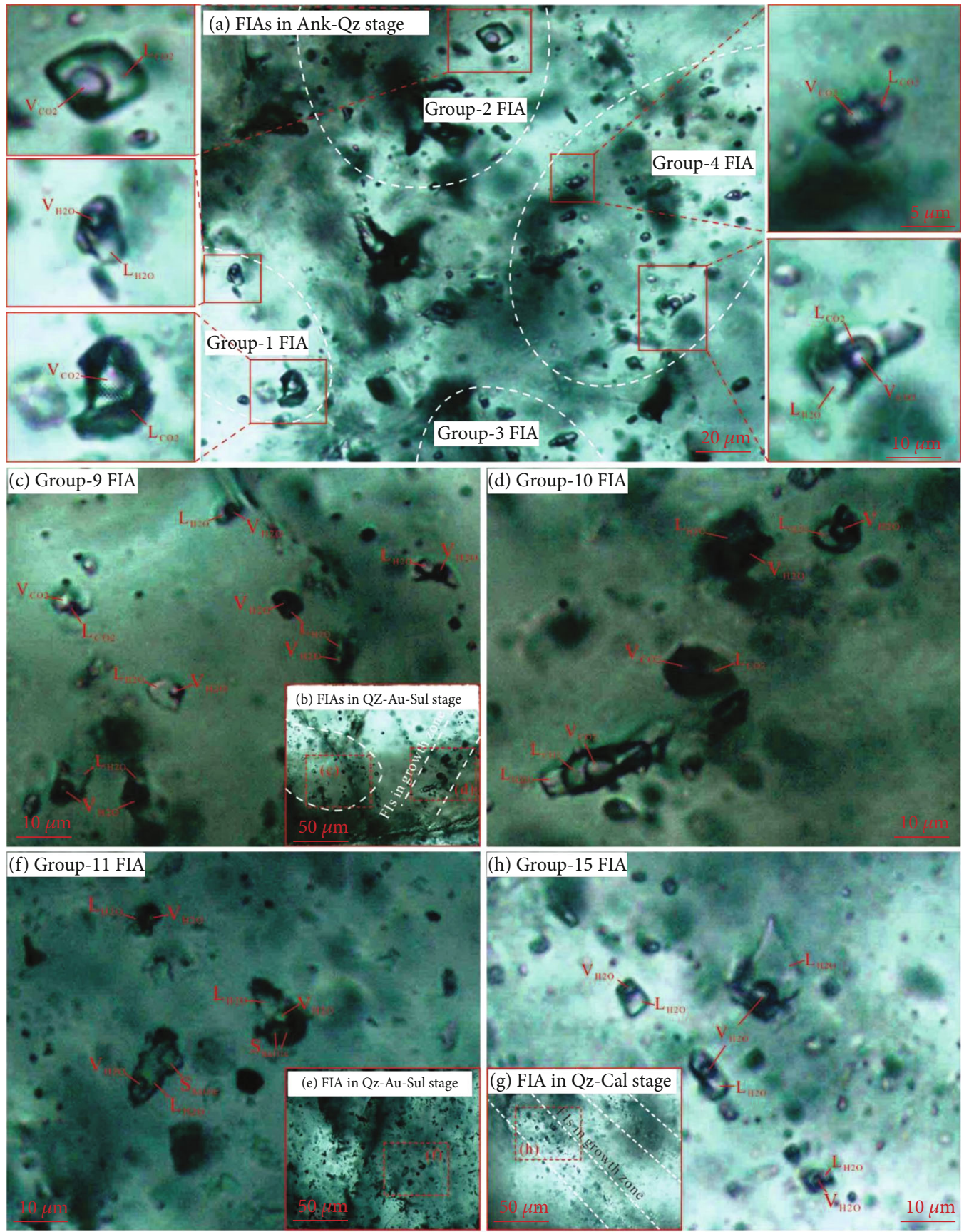

(i) Secondary FIs along the quartz fissure

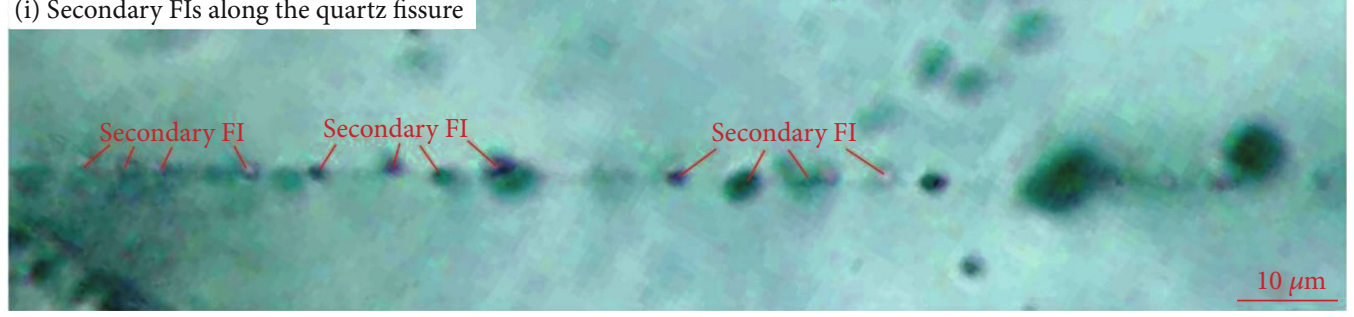

Figure 6: Photomicrographs of fluid inclusions assemblages (FIAs) in the hydrothermal quartz from the Dagangou Au-Ag-Cu-Sb deposit. (a) FIAs showing groups of coexisting primary type I, II, and III FIs in Ank-Qz-Py stage, which are distributed randomly in quartz, indicating heterogeneous entrapment; (b) FIAs showing groups of coexisting primary type I, II, and III FIs in Qz-Au-Sul stage, which are distributed randomly or along growth zone in quartz, indicating heterogeneous entrapment; (c) Group-9 FIA consisting of primary type I and III FI, distributed randomly. (d) Group-10 FIA consisting of primary type I, II, and III FIs, distributed along growth zone; (e, f) Group-11 FIA consisting of primary type III and IV FIs in the Qz-Au-Sul stage quartz, distributed randomly; (g, h) Group-15 FIA consisting of primary type III FIs in the Qz-Cal stage quartz, distributed along growth zone; (i) the secondary FIs distributed along the quartz fissure. 
6 groups of FIAs; the quartz in the Qz-Au-Sul stage mainly contains type II and III FIs with a few type I and IV FIs and are classified into 5 groups of FIAs; the FIs in the QzCal stage are dominantly type III and liquid monophase FIs, which are further classified into 4 groups of FIAs (Table 2). There are differences between each stage in the phases, composition, degree of filling, and relationship of fluids at room temperature. Generally, the fluid in the AnkQz-Py stage is enriched in $\mathrm{CO}_{2}, \mathrm{H}_{2} \mathrm{O}$, and other vapours, which is characterized by many type I FIs, very intense Raman strength of $\mathrm{CO}_{2}$, and a high vapour/liquid ratio of $70 \%$ or higher, while the fluid in the Qz-Cal stage is a liquid-rich fluid with many liquid FIs, little $\mathrm{CO}_{2}$, and a low vapour/liquid ratio of $30 \%$ or lower. The quartz in the Qz-Au-Sul stage contains all four types of FIs, which have a moderate Raman strength of $\mathrm{CO}_{2}$ and vapour/liquid ratio but a high salinity of type IV FI. This shows that the vapour component continued to decrease from the Ank-Qz-Py to Qz-Au-Sul stage, resulting in the fluid in the Qz-Cal stage evolving into a liquid-rich fluid.

\section{Analytical Methods}

5.1. Laser Raman Spectroscopy. Laser Raman spectral analysis was undertaken at the Geological Fluid Laboratory of Jilin University using a Renishaw System 1000 laser Raman instrument with a $514 \mathrm{~nm} \mathrm{Ar}^{+}$laser, scanning range of $4500-850 \mathrm{~cm}^{-1}$, accuracy of $\pm 1 \mathrm{~cm}^{-1}$, slit width of $25 \mu \mathrm{m}$, and test integration time of $120 \mathrm{~s}$. The results are shown in Figure 7.

5.2. Microthermometry. FIs in quartz were studied to determine the temperature, salinity, density, pressure, and depth of trapping of the fluids. Prior to analysis, approximately eight double-sided polished inclusion wafers $(0.05-0.2 \mathrm{~mm}$ thick) were prepared.

A microthermometric study of FIs was carried out using a Linkam THMS 600 programmable heating-freezing stage [44] at the Geological Fluid Laboratory of Jilin University. Most measurements were made at a heating rate of 0.2 to $0.4^{\circ} \mathrm{C} / \mathrm{min}$. Carbonic phase melting $\left(T_{\mathrm{m}(\mathrm{CO} 2)}\right)$ and clathrate melting $\left(T_{\mathrm{m}(\mathrm{cla})}\right)$ were determined by temperature cycling [45]; the heating rate near $T_{\mathrm{m}(\mathrm{CO} 2)}$ and $T_{\mathrm{m}(\mathrm{cla})}$ was 0.1 to $0.2^{\circ} \mathrm{C} / \mathrm{min}$ during the measurements. The measurement accuracy was ensured by calibration against the triple point of pure $\mathrm{CO}_{2}\left(-56.6^{\circ} \mathrm{C}\right)$, the freezing point of water $\left(0.0^{\circ} \mathrm{C}\right)$, and the critical point of water $\left(374.1^{\circ} \mathrm{C}\right)$ using synthetic fluid inclusions supplied by FLUID INC. The reproducibility of measurements was $\pm 0.2^{\circ} \mathrm{C}$ below $+30^{\circ} \mathrm{C}$ and $\pm 2^{\circ} \mathrm{C}$ at temperatures of final homogenization when the chips were centred in the specimen holder [46]. $T_{\mathrm{h}}$ values and halite consumption temperatures $\left(T_{\mathrm{m}(\mathrm{S})}\right)$ were determined for halitebearing triphase inclusions.

The microthermometric data for all the FIs are summarized in Table 2 and Figures 7 and 8. Calculations of salinity, the mole fraction of components $\left(X_{\mathrm{H} 2 \mathrm{O}}, X_{\mathrm{CO} 2}\right.$, and $\left.X_{\mathrm{NaCl}}\right)$, the densities of carbonic and bulk fluids, the salinities from clathrate melting temperatures, and the bulk molar volumes of the FIs were made using FLUIDS software [47].

5.3. Stable Isotope Analysis. S, H, and $\mathrm{O}$ isotope analyses were undertaken at the Analytical Laboratory of the Beijing Research Institute of Uranium Geology. The S isotope analyses were performed using a MAT-253 stable isotope ratio mass spectrometer. $\delta^{34} \mathrm{~S}$ values are analysed in thirteen sulfides (e.g., stibnite, pyrite, and chalcopyrite) from the Qz-Au-Sul stage. The sampled location, mineralization stage, and analysed results of the $\mathrm{S}$ isotopic samples are listed in Table 3. Sulfur isotopic compositions of sulfide minerals were measured using the conventional combustion method, and the testing procedure is described by Liu et al. [48]. The results are reported as $\delta^{34} \mathrm{~S}$ relative to the Vienna-Canyon Diablo Troilite (VCDT) standard, and the analytical precision was $\pm 0.2 \%$.

A total of eight samples were used for $\mathrm{H}-\mathrm{O}$ isotope analysis. First, the 40-60 mesh quartz inclusion samples are weighed at $5-10 \mathrm{mg}$, baked in a $105^{\circ} \mathrm{C}$ constant temperature oven for more than 4 hours, and then wrapped in a clean and dry tin cup for use. Second, the air inside the elemental analyser Flash EA was flushed with high purity helium to reduce the $\mathrm{H}_{2}$ background. The sample can be tested when the temperature rises to $1400^{\circ} \mathrm{C}$ and the background drops below $50 \mathrm{mV}$. The sample burst in a ceramic tube containing vitreous carbon, releasing $\mathrm{H}_{2} \mathrm{O}, \mathrm{H}_{2}$, and other $\mathrm{H}$-containing gases. $\mathrm{H}_{2} \mathrm{O}$ and other possible organic matter can be reduced with glass carbon at high temperature to reduce the $\mathrm{H}$ containing gas to $\mathrm{H}_{2}$. Finally, $\mathrm{H}_{2}$ was driven by high purity helium flow into a MAT-253 gas isotope mass spectrometer for analysis. The results are reported as $\delta \mathrm{D}_{\mathrm{V} \text {-SMOW }}$ values with the Standard Mean Ocean Water (SMOW) as the standard, and the analysis accuracy was better than $\pm 1 \%$. The reference standards of hydrogen isotopes are the national standard materials of Peking University and Lanzhou standard water, whose $\delta \mathrm{D}_{\mathrm{V}-\mathrm{SMOW}}$ values are $-64.8 \%$ and $-84.55 \%$, respectively.

First, the samples were placed in a vacuum of $10^{-3} \mathrm{~Pa}$ and reacted with pure bromine pentafloride at a constant temperature of $500-680^{\circ} \mathrm{C}$ for 14 hours to release $\mathrm{O}_{2}$ and impurity components. Second, pure $\mathrm{O}_{2}$ reacts with graphite to produce $\mathrm{CO}_{2}$ at $700^{\circ} \mathrm{C}$ and a platinum catalyst after separating $\mathrm{SiF} 4, \mathrm{BrF} 3$, and other impurity components by the freezing method. Finally, $\mathrm{CO}_{2}$ was collected by the freezing method, and the $\mathrm{O}$ isotope composition was analysed by MAT-253 gas isotope mass spectrometry. The results are reported as $\delta^{18} \mathrm{O}_{\mathrm{V} \text {-SMOW }}$ values with SMOW as the standard, and the analysis accuracy was better than $\pm 0.2 \%$ o. The reference standards of oxygen isotopes are the quartz standards of GBW-04409 and GBW-04410, whose $\delta^{18} \mathrm{O}$ values are $11.11 \pm 0.06 \%$ and $-1.75 \pm 0.08 \%$, respectively. Oxygen isotopic compositions of hydrothermal waters in equilibrium with quartz were calculated using an extrapolation of the fractionation formula of $1000 \ln \alpha_{\text {quartz-water }}=3.38 \times 10^{6} \cdot T^{-2}-$ 3.40 from [49]. The sampled location, mineralization stage, and analysed results of the $\mathrm{H}$ and $\mathrm{O}$ isotope samples are listed in Table 4. 


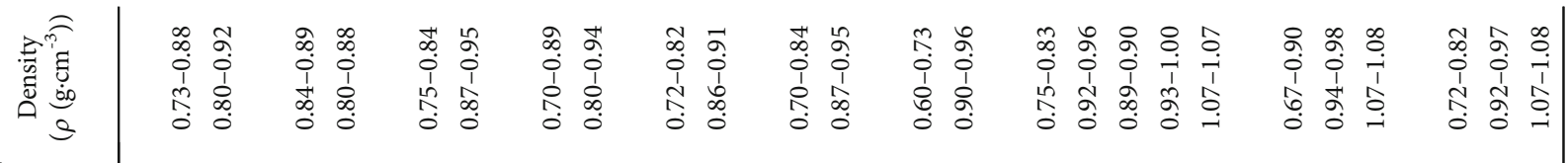

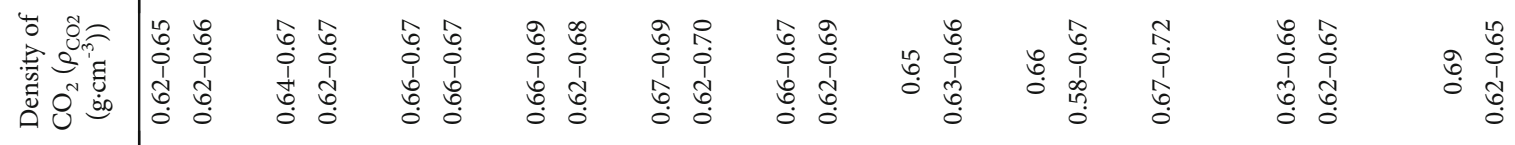

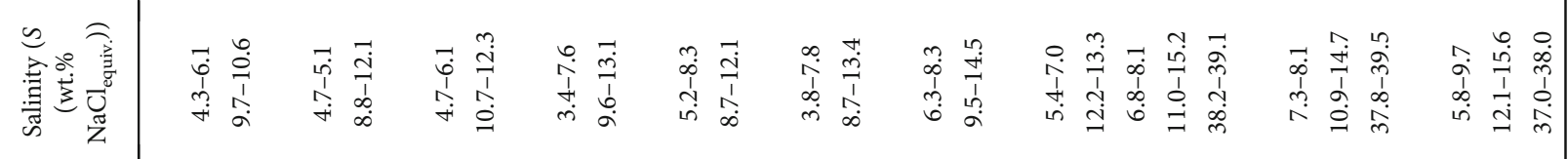

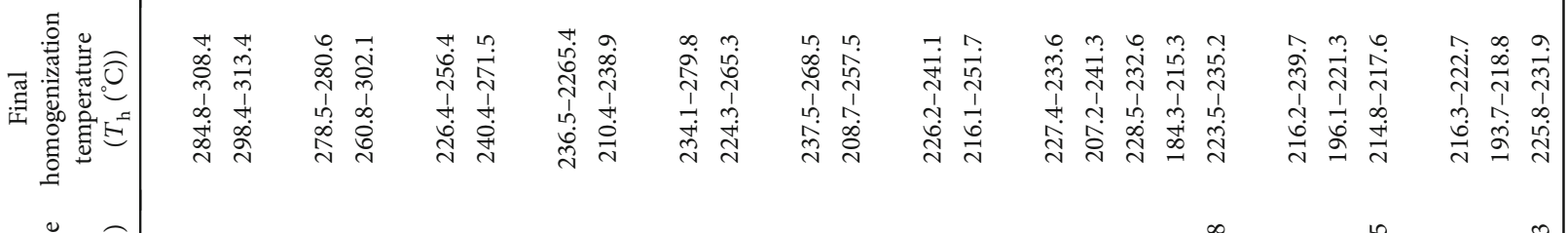

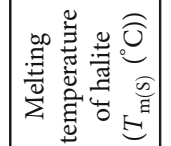

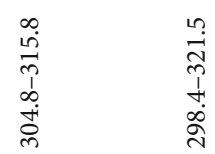

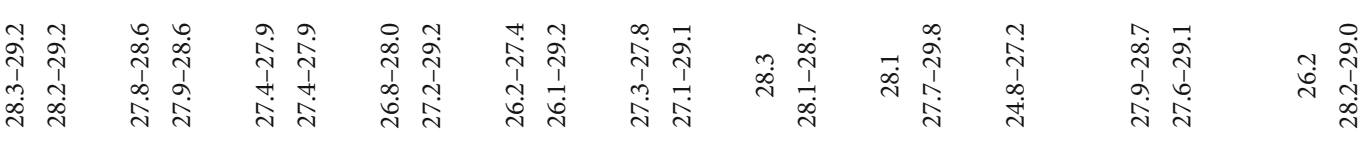
范 卷

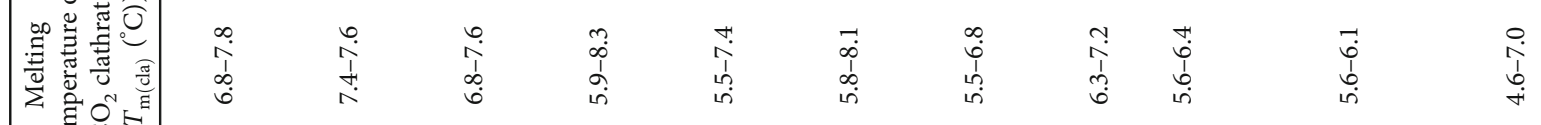
$8=$

焉密导

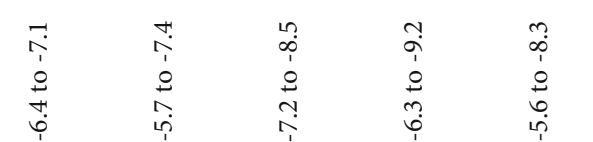

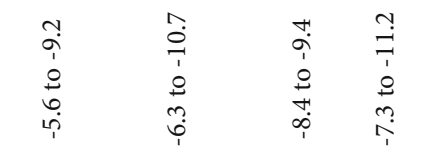

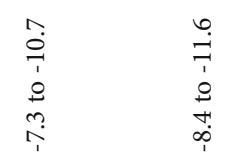

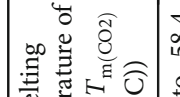

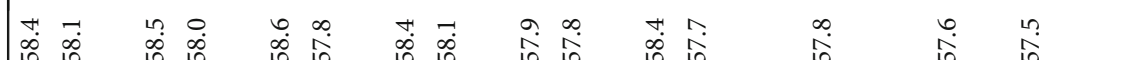

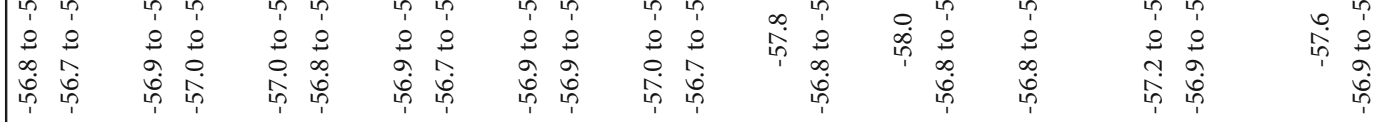

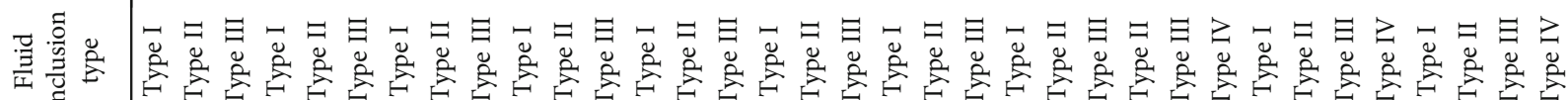

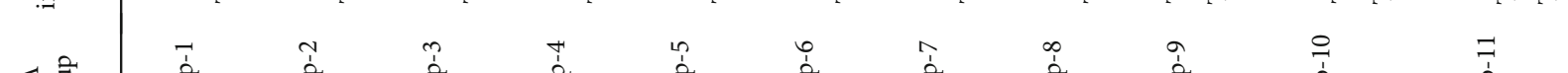

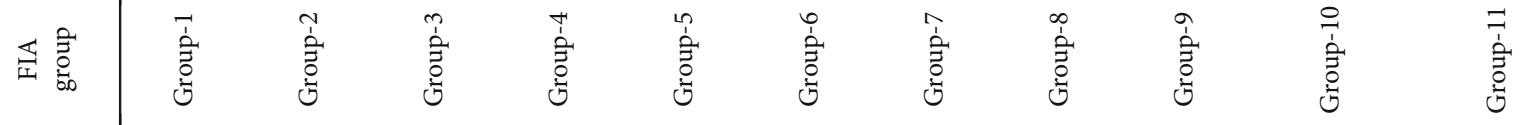

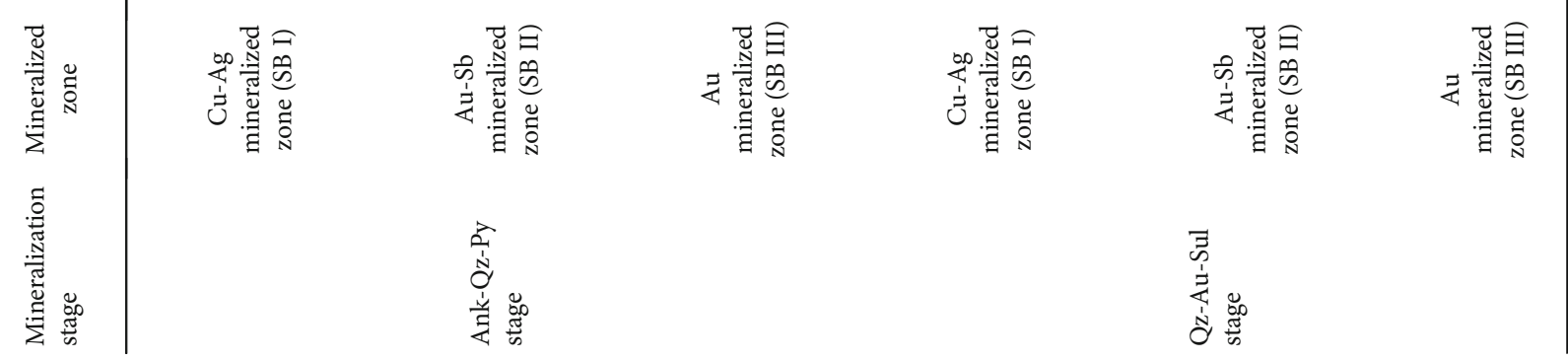




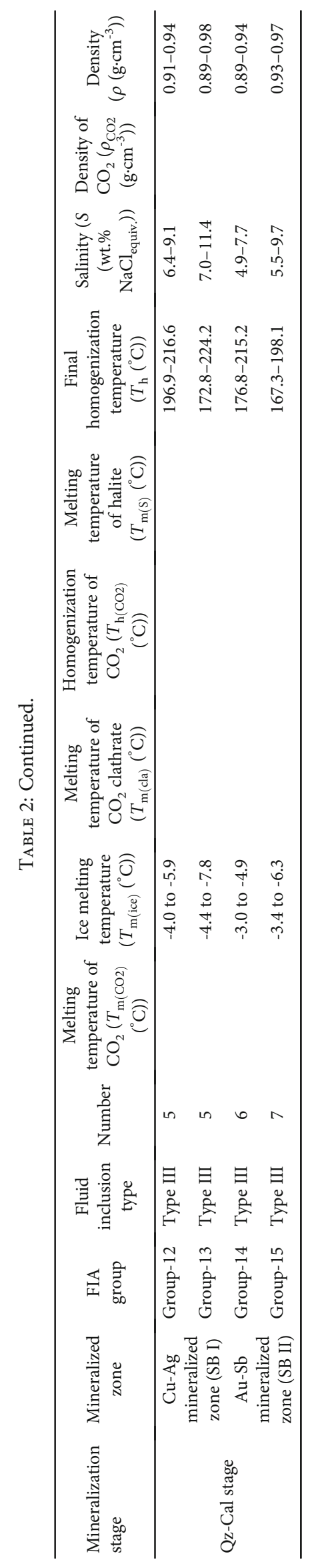




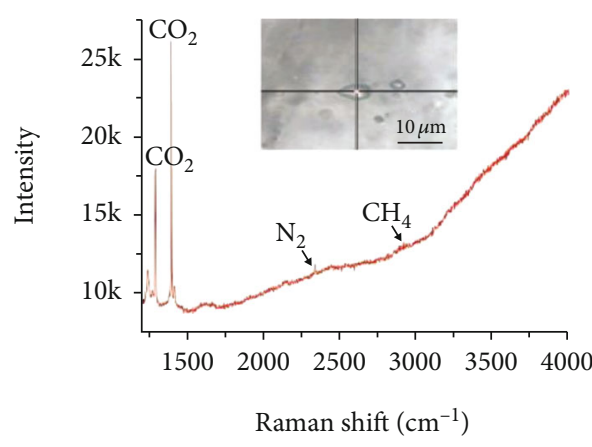

(a)

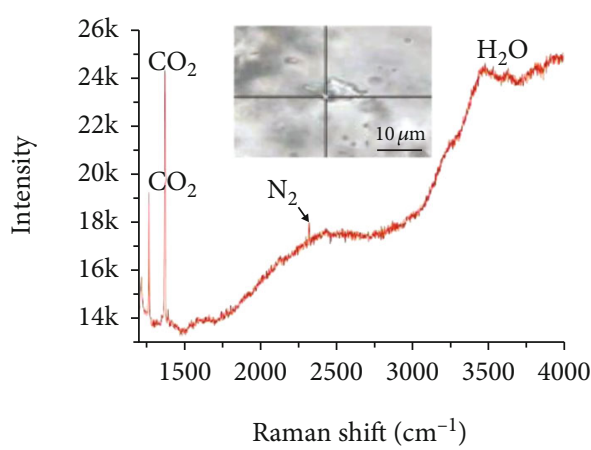

(c)

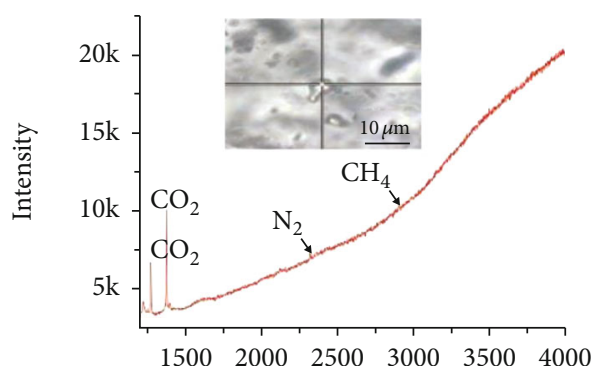

Raman shift $\left(\mathrm{cm}^{-1}\right)$

(e)

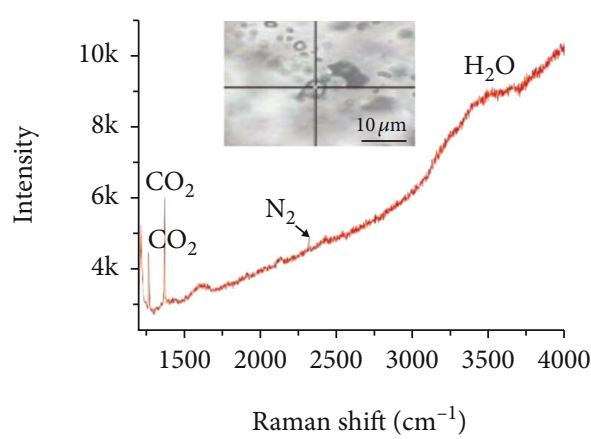

(g)

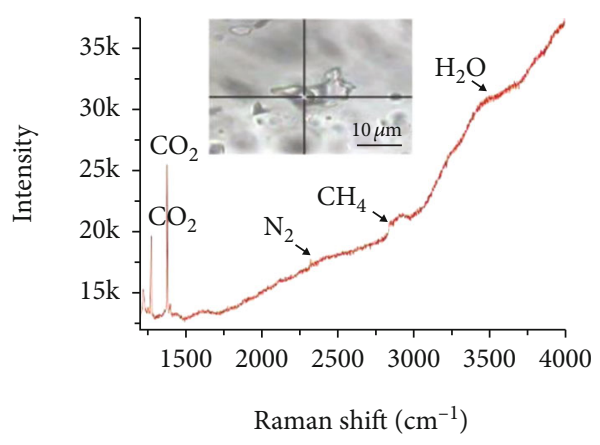

(b)

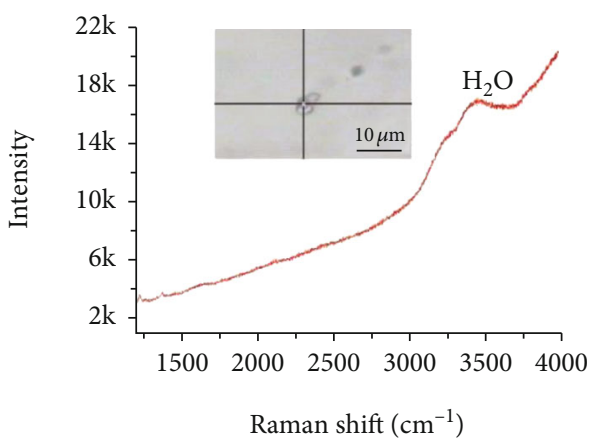

(d)

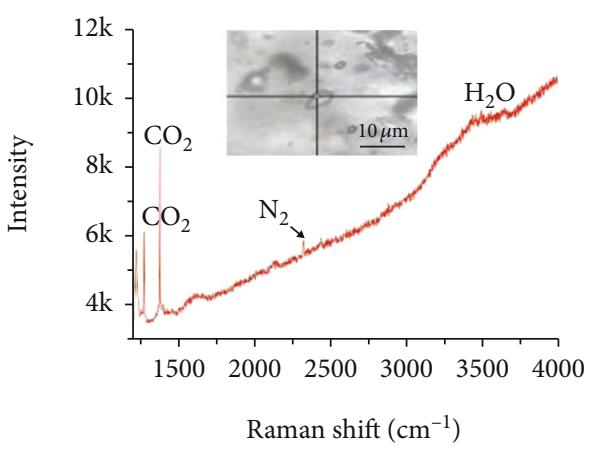

(f)

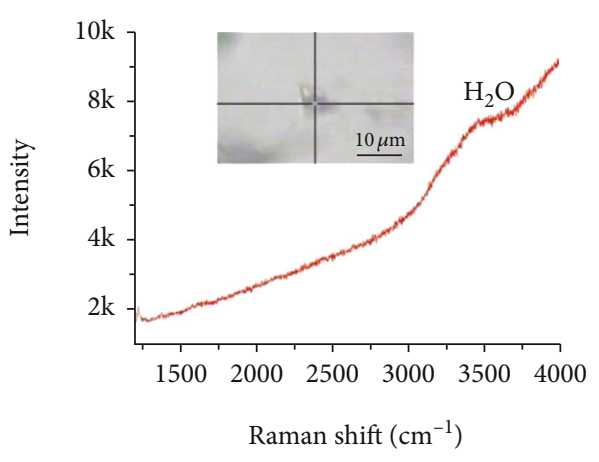

(h)

Figure 7: Continued. 


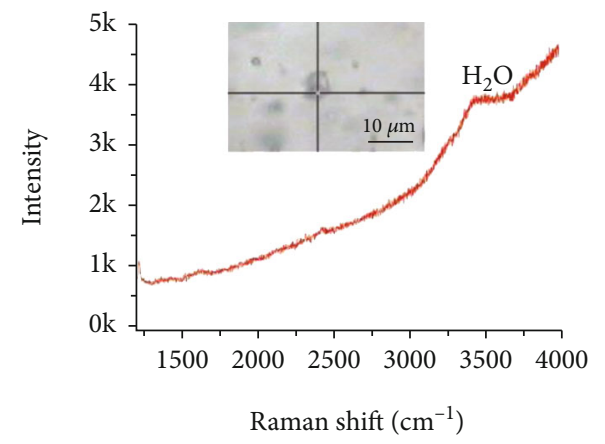

(i)

Figure 7: Laser Raman spectra of FIs from the Dagangou Au-Ag-Cu-Sb deposit. (a) Type I FIs in Ank-Qz-Py stage; (b, c) type II FIs in Ank-Qz-Py stage; (d) type III FIs in Ank-Qz-Py stage; (e) type I FIs in Qz-Au-Sul stage; (f, g) type II FIs in Qz-Au-Sul stage; (h) type III FIs in Qz-Au-Sul stage; (i) type III FIs in Qz-Cal stage.

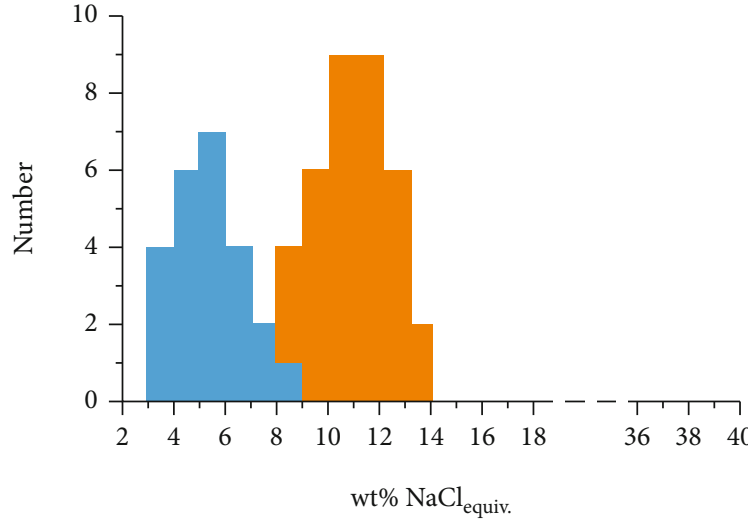

- Type II fluid inclusion

- Type III fluid inclusion

(a) Ore-forming fluids in Ank-Qz-Py stage

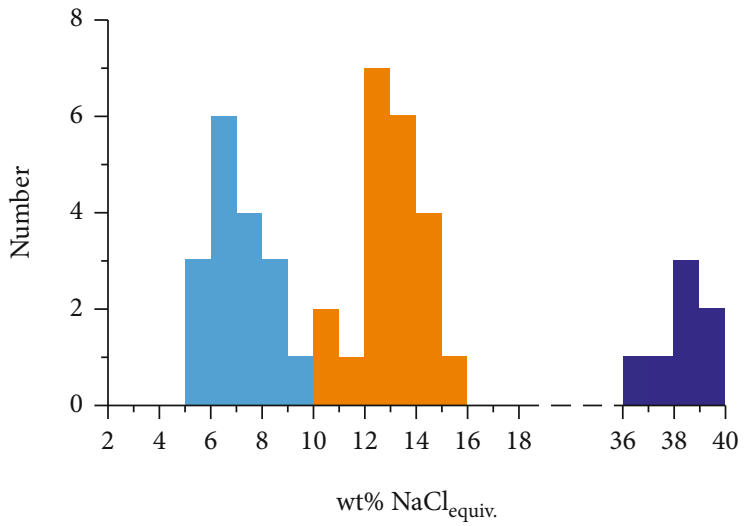

Type II fluid inclusion

- Type III fluid inclusion

- Type IV fluid inclusion

(b) Ore-forming fluids in Qz-Au-Sul stage

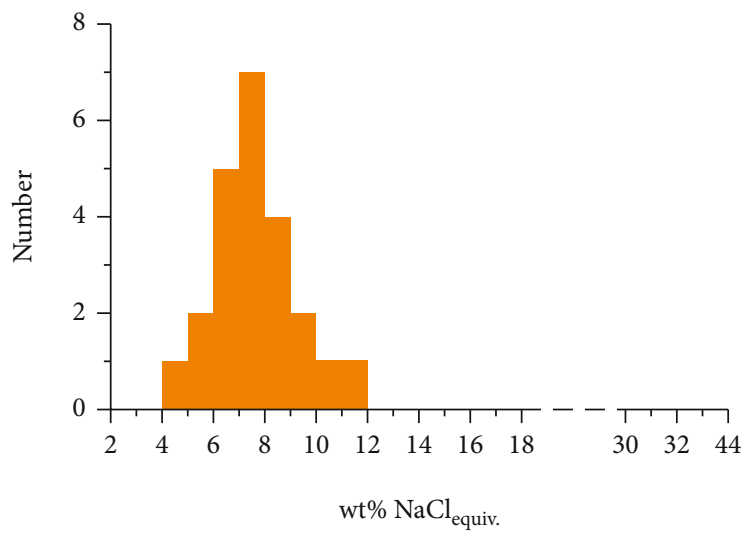

Type III fluid inclusion

(c) Ore-forming fluids in Qz-Cal stage

FIgURE 8: Histograms of fluid inclusion salinity for the Dagangou Au-Ag-Cu-Sb deposit.

\section{Analytical Results}

6.1. Laser Raman Spectroscopy. Representative type I, II, and III FIs from all three stages were analysed by laser Raman spectroscopy. The vapour phase of the Ank-Qz-Py stage FIs mainly contains $\mathrm{CO}_{2}$ and $\mathrm{H}_{2} \mathrm{O}$ with comparatively little $\mathrm{N}_{2}$, $\mathrm{CH}_{4}$, and $\mathrm{C}_{2} \mathrm{H}_{6}$, as indicated by laser Raman spectra (Figures 7(a)-7(d)). The vapour phases of the Qz-Au-Sul 
TABle 3: The $\delta^{34} \mathrm{~S}$ values of sulfide of the Dagangou Au-Ag-Cu-Sb deposit.

\begin{tabular}{|c|c|c|c|c|c|c|}
\hline Mineralized zone & Sampled location & $\begin{array}{l}\text { Mineralization } \\
\text { stage } \\
\end{array}$ & Sample name & Ore type & $\begin{array}{c}\text { Analysed } \\
\text { sulfide }\end{array}$ & $\begin{array}{l}\delta^{34} \mathrm{~S}_{\mathrm{V}-} \\
{ }_{\mathrm{CDT}}(\% 0) \\
\end{array}$ \\
\hline \multirow{2}{*}{$\begin{array}{l}\text { Mineralized } \mathrm{Cu} \text {-Ag zone } \\
\text { (SB I) }\end{array}$} & \multirow{2}{*}{$\mathrm{K} 1 \mathrm{Cu}$ ore body } & \multirow{2}{*}{ Qz-Au-Sul stage } & \multirow{2}{*}{ DGG-TC24-B 2} & \multirow{2}{*}{$\mathrm{Cu}-(\mathrm{Sb})$ ore } & Pyrite & 4.6 \\
\hline & & & & & Chalcopyrite & 3.8 \\
\hline \multirow{9}{*}{$\begin{array}{l}\text { Mineralized Au-Sb zone } \\
\text { (SB II) }\end{array}$} & \multirow{4}{*}{ K8 Au ore body } & \multirow{4}{*}{ Qz-Au-Sul stage } & \multirow{2}{*}{ DGG-TC52-B 2} & \multirow{2}{*}{$\mathrm{Sb}-\mathrm{Au}$ ore } & Stibnite & 3.9 \\
\hline & & & & & Pyrite & 5.1 \\
\hline & & & DGG-TC52-B ${ }_{5}$ & $\mathrm{Sb}-\mathrm{Au}$ ore & Stibnite & 3.5 \\
\hline & & & DGG-TC54-B 6 & $\mathrm{Sb}-\mathrm{Au}$ ore & Stibnite & 3.6 \\
\hline & \multirow{3}{*}{ K9 Sb ore body } & \multirow{3}{*}{ Qz-Au-Sul stage } & DGG-TC52-B 8 & $\begin{array}{l}\text { Stibnite-bearing altered } \\
\text { rocks }\end{array}$ & Stibnite & 3.4 \\
\hline & & & \multirow{2}{*}{ DGG-TC54-B 9} & \multirow{2}{*}{$\mathrm{Sb}-\mathrm{Cu}$ ore } & Stibnite & 3.9 \\
\hline & & & & & Chalcopyrite & 4.3 \\
\hline & \multirow{2}{*}{$\begin{array}{l}\text { KH12 Sb-mineralized } \\
\text { body }\end{array}$} & \multirow{2}{*}{ Qz-Au-Sul stage } & DGG-TC56-B 2 & Stibnite ore & Stibnite & 3.9 \\
\hline & & & DGG-TC56-B 4 & Stibnite ore & Stibnite & 4.1 \\
\hline \multirow{2}{*}{$\begin{array}{l}\text { Mineralized Au zone } \\
\text { (SB III) }\end{array}$} & \multirow{2}{*}{$\begin{array}{c}\text { KH13 Au-mineralized } \\
\text { body }\end{array}$} & \multirow{2}{*}{ Qz-Au-Sul stage } & \multirow{2}{*}{ DGG-TC31-B 1} & \multirow{2}{*}{ Au-bearing ore } & Pyrite & -1.4 \\
\hline & & & & & Pyrite & 3.7 \\
\hline
\end{tabular}

stage FIs are dominated by $\mathrm{CO}_{2}$ and $\mathrm{H}_{2} \mathrm{O}$ with trace amounts of $\mathrm{N}_{2}$ and $\mathrm{CH}_{4}$ (Figures $7(\mathrm{e})-7(\mathrm{~h})$ ), but the $\mathrm{CO}_{2}$ Raman intensity is weaker than that in the Ank-Qz-Py stage. In comparison, the vapour phase of the Qz-Cal stage FIs is mainly $\mathrm{H}_{2} \mathrm{O}$ (Figure $7(\mathrm{i})$ ). Therefore, the vapour components of ore-forming fluids that formed the Dagangou deposit consist of $\mathrm{CO}_{2}-\mathrm{H}_{2} \mathrm{O}-\mathrm{CH}_{4}-\mathrm{N}_{2}-\mathrm{C}_{2} \mathrm{H}_{6}$.

Therefore, ore-forming fluid in the Dagangou deposit approximately belongs to the $\mathrm{NaCl}-\mathrm{H}_{2} \mathrm{O}-\mathrm{CO}_{2}$ system, although it contains minor other vapours, such as $\mathrm{CH}_{4}, \mathrm{~N}_{2}$, and $\mathrm{C}_{2} \mathrm{H}_{6}$, and other chlorides, including $\mathrm{KCl}, \mathrm{CaCl}_{2}$, and likely $\mathrm{MgCl}_{2}$ and Fe chlorides. This FI system is used to calculate the salinity and density in this paper.

6.2. Homogenization Temperature, Salinity, and Density. Microthermometric data were measured in some representative primary FIs. The microthermometric data and other related calculations for all FIs are summarized in Table 2 and Figures 8 and 9. Calculations of salinity, the mole fractions of components $\left(X_{\mathrm{H} 2 \mathrm{O}}, X_{\mathrm{CO} 2}\right.$, and $\left.X_{\mathrm{NaCl}}\right)$, the densities of carbonic and bulk fluids, the salinities from clathrate melting temperatures, and the bulk molar volumes of FIs were made using FLUIDS software [47]. The salinity and density of the type IV FIs were calculated according to [50].

(i) Fluid inclusions in the Ank-Qz-Py stage: this stage mainly contains the FIs of types I, II, and III, and their microthermometric results are listed in Table 2. The melting temperatures of the $\mathrm{CO}_{2}$ phase $\left(T_{\mathrm{m}(\mathrm{CO} 2)}\right)$ for type $\mathrm{I}$ and II FIs are -58.6 to $-56.8^{\circ} \mathrm{C}$ and -58.1 to $-56.7^{\circ} \mathrm{C}$, respectively. The melting temperatures are lower than that of pure $\mathrm{CO}_{2}\left(-56.6^{\circ} \mathrm{C}\right)$, indicating the presence of other vapours, such as $\mathrm{CH}_{4}$ and $\mathrm{N}_{2}$. The homogenization temperature of the $\mathrm{CO}_{2}$ phase $\left(T_{\mathrm{h}(\mathrm{CO} 2)}\right)$ of type I FIs is $26.2-29.2^{\circ} \mathrm{C}$, and its $\mathrm{CO}_{2}$ density $\left(\rho_{\mathrm{CO} 2}\right)$ is $0.62-0.69 \mathrm{~g} / \mathrm{cm}^{3}$.
The melting temperature of $\mathrm{CO}_{2}$ clathrates $\left(T_{\mathrm{m}(\mathrm{cla})}\right)$ in type II FIs is $5.5-8.3^{\circ} \mathrm{C}$ while heating up after cooling down, yielding salinities of $3.4-8.3$ wt. $\% \mathrm{NaCl}_{\text {equiv. }}$, with values concentrated in the range of $4-6$ wt.\% $\mathrm{NaCl}_{\text {equiv. }}$ (Figure 8). $\mathrm{CO}_{2}$ clathrates have $\mathrm{CO}_{2}$ homogenization-to-vapour temperatures $\left(T_{\mathrm{h}(\mathrm{CO} 2)}\right)$ of $26.1-29.2^{\circ} \mathrm{C}$, yielding $\mathrm{CO}_{2}$ densities $\left(\rho_{\mathrm{CO} 2}\right)$ of $0.62-0.70 \mathrm{~g} / \mathrm{cm}^{3}$. The corresponding bulk inclusion densities are $0.70-0.89 \mathrm{~g} / \mathrm{cm}^{3}$, and they homogenize to liquid at $226.4-$ $308.4^{\circ} \mathrm{C}$ with values concentrated in the range of $240-270^{\circ} \mathrm{C}$ (Figure 9).

The ice melting temperatures $\left(T_{\mathrm{m} \text { (ice) }}\right)$ of type III FIs range from -9.2 to $-5.6^{\circ} \mathrm{C}$, yielding salinities of $8.7-13.4$ wt. $\% \mathrm{NaCl}_{\text {equiv. }}$, with values concentrated in the range of 10-12 wt.\% $\mathrm{NaCl}_{\text {equiv. }}$ (Figure 8). These FIs homogenize at 208.7-313. $4^{\circ} \mathrm{C}$, with values concentrated in the range of $220-240^{\circ} \mathrm{C}$ (Figure 9); their densities range from 0.80 to $0.95 \mathrm{~g} / \mathrm{cm}^{3}$.

(ii) Fluid inclusions in the Qz-Au-Sul stage: the microthermometric data of the four types of FIs in the $\mathrm{Qz}-\mathrm{Au}-\mathrm{Sul}$ stage are listed in Table 2. The $T_{\mathrm{m}(\mathrm{CO} 2)}$ values of type I and II FIs are -58.5 to $-57.2^{\circ} \mathrm{C}$ and -57.8 to $-56.8^{\circ} \mathrm{C}$, respectively, indicating the presence of other vapours (e.g., $\mathrm{CH}_{4}$ and $\mathrm{N}_{2}$ ). Type I FIs have $T_{\mathrm{h}(\mathrm{CO} 2)}$ values of $26.2-28.7^{\circ} \mathrm{C}$ and contain $\mathrm{CO}_{2}$ at densities of $0.63-0.69 \mathrm{~g} / \mathrm{cm}^{3}$.

The melting of $\mathrm{CO}_{2}$ clathrate $\left(T_{\mathrm{m}(\mathrm{cla})}\right)$ in the presence of $\mathrm{CO}_{2}$ liquid for type II FIs occurs between 4.6 and $7.2^{\circ} \mathrm{C}$, yielding salinities of 5.4-9.7 wt.\% $\mathrm{NaCl}_{\text {equiv. }}$, with values concentrated in the range of $6-7 \mathrm{wt} . \% \mathrm{NaCl}_{\text {equiv. }}$ (Figure 8), and their $T_{\mathrm{h}(\mathrm{CO} 2)}$ values are $24.8-29.8^{\circ} \mathrm{C}$. The densities of the $\mathrm{CO}_{2}$ phase are $0.58-0.72 \mathrm{~g} / \mathrm{cm}^{3}$, and the densities of bulk inclusions are $0.60-0.90 \mathrm{~g} / \mathrm{cm}^{3}$. Upon heating, these FIs finally homogenize at $216.2-241.1^{\circ} \mathrm{C}$, with values concentrated in the range of $210-240^{\circ} \mathrm{C}$ (Figure 9). 
TABle 4: The ore-forming fluid $\mathrm{H}-\mathrm{O}$ isotopes of the Dagangou Au-Ag-Cu-Sb deposit.

\begin{tabular}{|c|c|c|c|c|c|c|c|}
\hline $\begin{array}{l}\text { Mineralization } \\
\text { stage }\end{array}$ & Mineralized zone & $\begin{array}{l}\text { Sampled } \\
\text { location }\end{array}$ & Sample & $\begin{array}{c}\delta^{18} \mathrm{O}_{\text {V-SMOW }} \\
(\% \text { o })\end{array}$ & $\begin{array}{l}\delta \mathrm{D}_{\mathrm{V} \text {-SMOW }} \\
(\% \mathrm{o})\end{array}$ & $\begin{array}{c}\delta^{18} \mathrm{O}_{\mathrm{H} 2 \mathrm{O}} \\
(\%)\end{array}$ & $\begin{array}{c}\text { Calculated } \\
\text { temperature }\left({ }^{\circ} \mathrm{C}\right)\end{array}$ \\
\hline \multirow{3}{*}{$\begin{array}{l}\text { Ank-Qz-Py } \\
\text { stage }\end{array}$} & \multirow{3}{*}{$\begin{array}{l}\text { Au-Sb-mineralized } \\
\text { zone (SB II) }\end{array}$} & \multirow{3}{*}{$\begin{array}{c}\text { K8 Au ore } \\
\text { body }\end{array}$} & DGG-TC54-W 1 & 14.8 & -88.2 & 7.4 & 285 \\
\hline & & & DGG-TC52-W 4 & 14.5 & -90.0 & 7.1 & 285 \\
\hline & & & DGG-TC52-W ${ }_{5}$ & 14.1 & -86.8 & 6.7 & 285 \\
\hline \multirow{3}{*}{$\begin{array}{l}\text { Qz-Au-Sul } \\
\text { stage }\end{array}$} & \multirow{3}{*}{$\begin{array}{l}\text { Au-Sb-mineralized } \\
\text { zone (SB II) }\end{array}$} & \multirow{3}{*}{$\begin{array}{l}\text { K9 Sb ore } \\
\text { body }\end{array}$} & DGG-TC54-W 2 & 17.3 & -89.6 & 8.6 & 255 \\
\hline & & & DGG-TC52-W 6 & 17.3 & -89.7 & 8.6 & 255 \\
\hline & & & DGG-TC52-W 7 & 16.8 & -90.6 & 8.1 & 255 \\
\hline \multirow{2}{*}{ Qz-Cal stage } & \multirow{2}{*}{$\begin{array}{l}\text { Au-Sb-mineralized } \\
\text { zone (SB II) }\end{array}$} & \multirow{2}{*}{$\begin{array}{l}\text { K9 Sb ore } \\
\text { body }\end{array}$} & DGG-TC52-W & 14.6 & -95.7 & 4.3 & 224 \\
\hline & & & DGG-TC52-W 10 & 14.2 & -97.2 & 3.9 & 224 \\
\hline
\end{tabular}

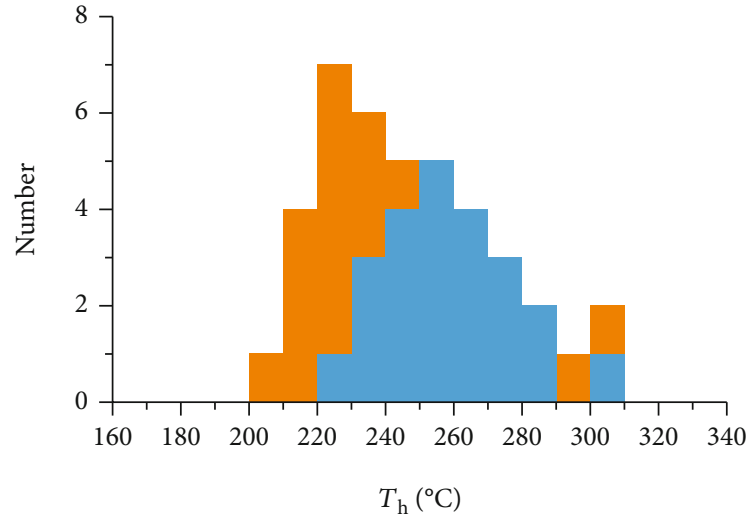

Type II fluid inclusion

Type III fluid inclusion

(a) Ore-forming fluids in Ank-Qz-Py stage

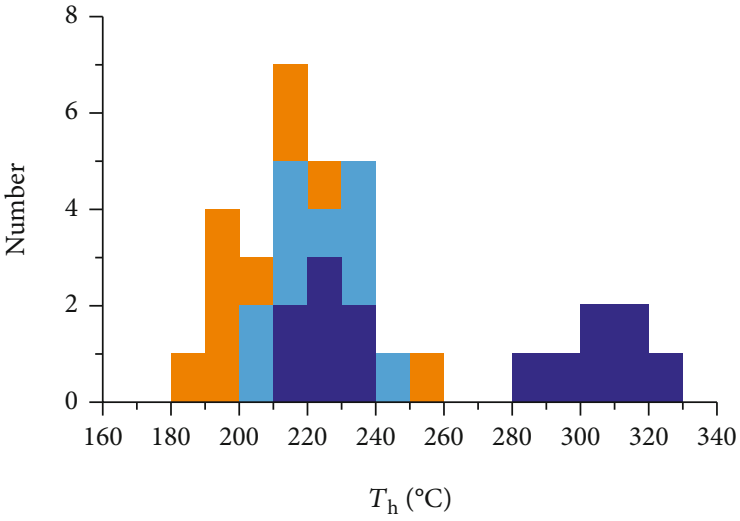

- Type II fluid inclusion

Type III fluid inclusion

- Type IV fluid inclusion

(b) Ore-forming fluids in Qz-Au-Sul stage

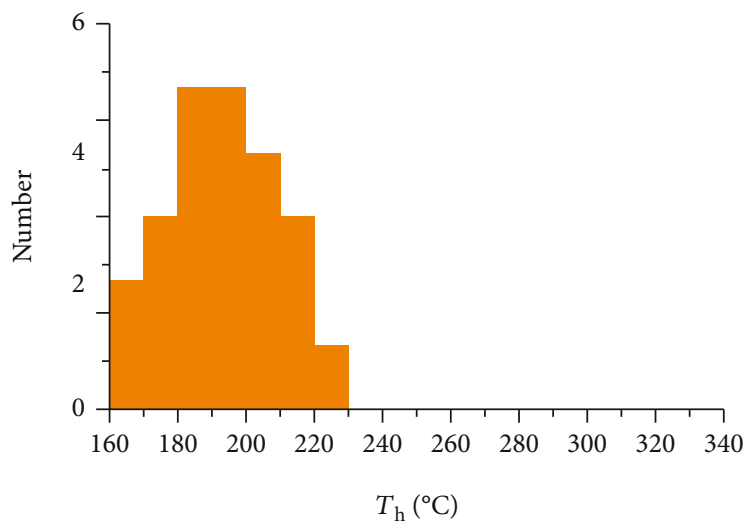

Type III fluid inclusion

(c) Ore-forming fluids in Qz-Cal stage

Figure 9: Histograms of fluid inclusion homogenization temperature for the Dagangou Au-Ag-Cu-Sb deposit.

The type III FIs in the Qz-Au-Sul stage show final homogenization to liquid temperatures $\left(T_{\mathrm{h}}\right)$ of $184.3-$ $251.7^{\circ} \mathrm{C}$, with values concentrated in the range of $210-$ $230^{\circ} \mathrm{C}$ (Figure 9), and ice melting temperature $\left(T_{\mathrm{m} \text { (ice) }}\right)$ values are in the range of -11.6 to $-6.3^{\circ} \mathrm{C}$. Their $T_{\mathrm{m} \text { (ice) }}$ values correspond to salinities from 9.5 to 15.6 wt.\% $\mathrm{NaCl}_{\text {equiv.' }}$ with values concentrated in the range of $12-14 \mathrm{wt} . \%$ $\mathrm{NaCl}_{\text {equiv. }}$ (Figure 8), and their densities are approximately $0.90-1.00 \mathrm{~g} / \mathrm{cm}^{3}$.

The vapour-liquid phase of type IV FIs has first homogenization temperature $\left(T_{\mathrm{h}}\right)$ to liquid at $214.8-235.2^{\circ} \mathrm{C}$ during heating, and as the temperature continued to rise, halite 
melted at $286.3-321.5^{\circ} \mathrm{C}\left(T_{\mathrm{m}(\mathrm{s})}\right)$ and eventually homogenized to the liquid phase. The melting temperature of halite $\left(T_{\mathrm{m}(\mathrm{S})}\right)$ yields salinities of $37.0-39.5 \mathrm{wt} . \% \mathrm{NaCl}_{\text {equiv. }}$ and densities of $1.07-1.08 \mathrm{~g} / \mathrm{cm}^{3}$.

(iii) Fluid inclusions in the Qz-Cal stage: FIs in the QzCal stage are mainly type III FIs with minor liquid monophase FIs, and the microthermometric data are shown in Table 2. Type III FIs are particularly common and have final $T_{\mathrm{h}}$ to liquid of 167.3$224.2^{\circ} \mathrm{C}$, with values concentrated in the range of $180-200^{\circ} \mathrm{C}$ (Figure 9). The $T_{\mathrm{m} \text { (ice) }}$ of type III FIs is -7.8 to $-3.0^{\circ} \mathrm{C}$, which yields salinities of $4.9-11.4$ wt.\% $\mathrm{NaCl}_{\text {equiv. }}$ with values concentrated in the range of $6-8$ wt.\% $\mathrm{NaCl}_{\text {equiv. }}$ (Figure 8 ), and their densities range from 0.89 to $0.97 \mathrm{~g} / \mathrm{cm}^{3}$.

In conclusion, microthermometric FI data are significantly different between mineralization stages. The homogenization temperatures in the Ank-Qz-Py to Qz-Au-Sul to Qz-Cal stages are $208.7-313.4^{\circ} \mathrm{C}\left(252^{\circ} \mathrm{C}\right.$ average $), 184.3-$ $251.7^{\circ} \mathrm{C}\left(220^{\circ} \mathrm{C}\right.$ average $)$, and $167.3-224.2^{\circ} \mathrm{C}\left(195^{\circ} \mathrm{C}\right.$ average $)$, with salinities of 3.4-13.4 wt.\% (8.7 wt.\% average), 5.4-39.5 wt.\% (14.6 wt.\% average), and 4.9-11.4 wt.\% (7.7 wt.\% average) $\mathrm{NaCl}_{\text {equiv. }}$, respectively.

6.3. $S$ and H-O Isotopes. Seven stibnites have $\delta^{34} \mathrm{~S}$ values of $3.4-4.1 \%$ (3.8\% average), four pyrites have $\delta^{34} \mathrm{~S}$ values of $-1.4-5.1 \%$ o (3.0\% average), and two chalcopyrites have $\delta^{34} \mathrm{~S}$ values of $3.8-4.3 \%$ o (4.1\%o average), all of which plot within the field containing other gold-polymetallic deposits with the same metallogenic age in the $\operatorname{EKO}[2,4,17,18,24]$ (Figure 10).

$\mathrm{H}$ - O isotopes were analysed in a total of eight hydrothermal quartz samples to reveal the fluid compositions at each stage. The fluid $\delta \mathrm{D}$ and $\delta^{18} \mathrm{O}_{\mathrm{H} 2 \mathrm{O}}$ values of the Ank-Qz-Py stage are -90.0 to $-86.8 \%$ o and 6.7-7.4\%o, while those of the Qz-Au-Sul stage are -90.6 to $-89.6 \%$ and $8.1-8.6 \%$, respectively (Table 4). The fluid $\delta \mathrm{D}$ and $\delta^{18} \mathrm{O}_{\mathrm{H} 2 \mathrm{O}}$ values of the $\mathrm{Qz}-\mathrm{Cal}$ stage are -97.2 to $-95.7 \%$ and $3.9-4.3 \%$, respectively (Table 4 ).

The calculated temperature of Ank-Qz-Py and Qz-AuSul stages fluid are medium of the trapping temperature of $260-310^{\circ} \mathrm{C}$ and $230-280^{\circ} \mathrm{C}$ in Figure 10, and the Qz-Cal stage temperature is the highest of $224^{\circ} \mathrm{C}$.

\section{Discussion}

7.1. Physicochemical Conditions of Fluid Inclusion Trapping. Studies show that fluid immiscibility is a common phenomenon in the evolution of natural fluids [52-54], and it is believed that the immiscibility of $\mathrm{NaCl}-\mathrm{H}_{2} \mathrm{O}-\mathrm{CO}_{2}$ system fluids plays a significant role in the mineralization of gold deposits [55-58]. The fluid immiscibility of the $\mathrm{NaCl}-\mathrm{H}_{2} \mathrm{O}-$ $\mathrm{CO}_{2}$ system has been studied extensively by many researchers [59-62]. Among them, Frantz et al. [61] believed that immiscibility in the $\mathrm{NaCl}-\mathrm{H}_{2} \mathrm{O}-\mathrm{CO}_{2}$ system often occurred between $1-3 \mathrm{kbar}$ and $500-700^{\circ} \mathrm{C}$ and mainly depended on the pressure and temperature. In addition, the ratio of $\mathrm{CO}_{2} / \mathrm{H}_{2} \mathrm{O}$ is also very important for immiscibility. Lode gold deposits usually contain aqueous FIs, $\mathrm{H}_{2} \mathrm{O}-\mathrm{CO}_{2}$ FIs, $\mathrm{CO}_{2}$ FIs, and mineral-bearing FIs, the first three types of which dominate the FI type [57]. Ramboz et al. [52] suggested that the heterogeneous trapping of immiscible fluids would result in FI populations with variable phase ratios that homogenized in two different ways.

Clusters of type I, II, and III FIs are distributed randomly or along growth zones in the Dagangou hydrothermal quartz. They have varied vapour phases (e.g., $\mathrm{CO}_{2}, \mathrm{CO}_{2}-\mathrm{HO}_{2}$, and $\mathrm{H}_{2} \mathrm{O}$ ) and continuous variations in vapour/liquid ratios, type II FIs homogenize to the liquid or vapour phase, and some type IV FIs are also present in the Qz-Au-Sul stage. This indicates that these FIs were formed in heterogeneous trapping during fluid immiscibility of an originally uniform primary $\mathrm{CO}_{2}-\mathrm{H}_{2} \mathrm{O}-\mathrm{NaCl}$ fluid $[44,47,63]$. Type II FIs have higher homogenization temperatures, lower salinities, and lower densities than type III FIs but also have variable homogenization temperatures. Moreover, the microthermometric FI results are approximate for the FIA groups within a mineralization stage, and no more than $10 \%$ of FIs with different sizes and shapes have homogenization temperature variations greater than $15^{\circ} \mathrm{C}$ [41], all of which suggest that they are likely heterogeneous and captured synchronously or almost synchronously. This phenomenon has also been described in similar Au deposits elsewhere, such as Sigma and Star Lake Au deposits in Canada, and it is considered to be the result of several continuous fluid immiscibility events caused by fluctuations in pressure $[64,65]$.

Pressure-temperature conditions can be estimated from FIs by constructing isochores from microthermometric and fluid composition data $[44,46,66]$. Isochores were constructed for the FIs of Ank-Qz-Py and Qz-Au-Sul stages (Figure 11) based on the $\mathrm{H}_{2} \mathrm{O}-\mathrm{NaCl}-\mathrm{CO}_{2}$ system, which is dominated by saline solution and $\mathrm{CO}_{2}$, with less $\mathrm{CH}_{4}, \mathrm{~N}_{2}$, and $\mathrm{C}_{2} \mathrm{H}_{6}$ in the vapour phase. As such, we obtained corrected temperatures (trapping temperatures) for the Ank-Qz-Py and Qz-Au-Sul stages of $260-310^{\circ} \mathrm{C}$ and $230-280^{\circ} \mathrm{C}$, respectively (Figure 11). In trapped fluid inclusions in the process of fluid immiscibility, many researchers have suggested that the homogenization temperature and pressure of the trapping end-member components are similar and basically represent the trapping temperature and pressure $[44,63,67]$. The endmember composition inclusions trapped during these immiscibility events have similar homogenization temperatures and pressures and are close to the trapping temperatures and pressures for these FIs [44, 63, 67-69]. The homogenization temperature of type II FIs trapped in the Qz-Au-Sul stage may actually reflect their captured temperature as a result of oreforming fluid immiscibility. Since the Qz-Au-Sul stage is the peak of sulfide precipitation and mineralization of Dagangou, the homogeneous temperature $\left(230-280^{\circ} \mathrm{C}\right)$ in this stage approximately represents the formation temperature of this deposit (Figure 11).

The corrected pressures (trapping pressures) in the AnkQz-Py and Qz-Au-Sul stages are estimated to be 70-100 MPa 


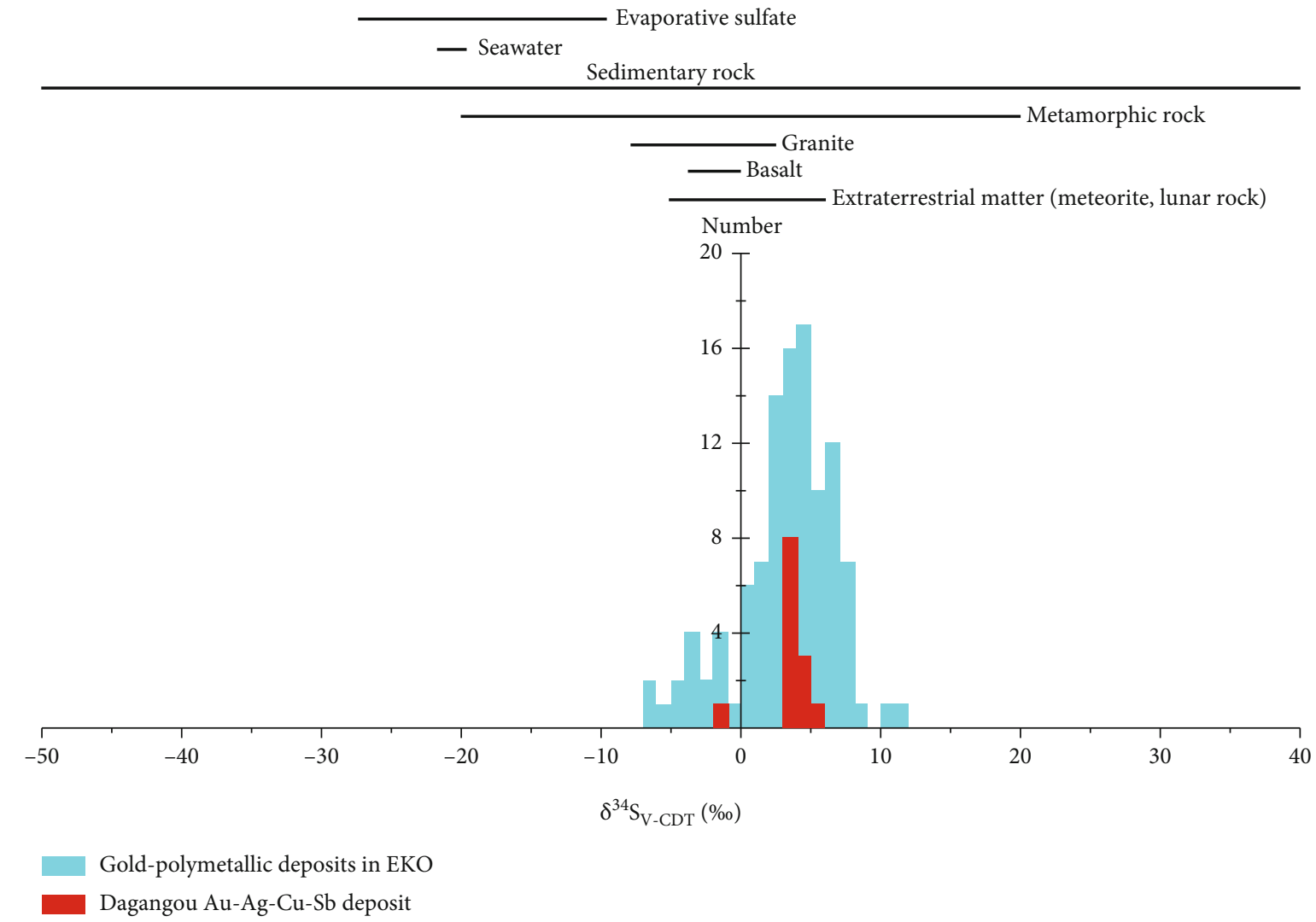

Figure 10: Histogram showing $\delta^{34} \mathrm{~S}$ value of different sulfides for the Dagangou Au-Ag-Cu-Sb deposit. The data of nature system are cited from Hoefs (1973) [51], and the data of gold-polymetallic deposits in EKO are collected from [2, 4, 17, 18, 24].

(average $85 \mathrm{Ma}$ ) and $55-85 \mathrm{MPa}$ (average $70 \mathrm{Ma}$ ), respectively (Figure 11). The pressure in the Qz-Au-Sul stage is lower than that in the Ank-Qz-Py stage, and we consider the trapping pressure in the Qz-Au-Sul stage (55-85 MPa) to be the mineralization pressure since most of the sulfide precipitation and mineralization took place in this stage. In turn, this yields a formation depth of $5.9-7.5 \mathrm{~km}$ for the Dagangou deposit, as defined by Sun et al. [70]. This result indicates that the Dagangou Au-Ag-Cu-Sb deposit formed at a mesozonal depth.

\subsection{Sources and Evolution of Sulfur and Ore-Forming Fluid.} The sulfides within the Dagangou deposit have $\delta^{34} \mathrm{~S}$ values of $-1.4-5.1 \%$ o (3.6\%o average), e.g., stibnite $3.4-4.1 \%$ o $(N=7$ ; $3.8 \%$ average), pyrite $-1.4-5.1 \%$ o $(N=4 ; 3.0 \%$ average $)$, and chalcopyrite $3.8-4.3 \%$ o $(N=2 ; 4.1 \%$ average $)$. They vary in a wide range and plot within the field of gold-polymetallic deposits in the EKO (Figure 10), which range from $-6.3 \%$ o to $11.1 \%$ and include pyrite, arsenopyrite, chalcopyrite, stibnite, galena, and sphalerite $[2,4,17,18,24]$. These $\delta^{34} S$ values can be divided into two distinct groups: a group of negative values (concentrated in the range of -4 to $-2 \%$ ) and a group of positive values (concentrated in the range of 3-5\%o) (Figure 10). Many researchers suggest that the approximately zero $\delta^{34} S$ values $( \pm 2 \%$ ) of sulfides are derived from magmatic fluids $[2,4,17,18,24]$. However, both the negative values and positive values are distant from the zero $\delta^{34} S$ values $( \pm 2 \%)$, which suggests that the sulfur with Dagangou is unlikely to have originated from magma. Moreover, the sulfide $\delta^{34}$ S values within the Dagangou deposit deviate from the $\delta^{34}$ S values of magma but plot in the field containing sedimentary and metamorphic rocks in Figure 10. As mentioned above, the wall rock of the Dagangou deposit mainly comprises Permian-Triassic sandstones, sand slate, siltstone, carbonaceous slate, and carbonatite. Therefore, we suggest that the source of sulfur within the Dagangou deposit is dominated by sedimentary sulfur (e.g., sulfur from the wall rock of schist, carbonaceous slate, and black rock series) with minor magmatic sulfur.

The H-O isotope data show that the $\delta \mathrm{D}_{\mathrm{V} \text {-SMOw }}$ values of ore-forming fluid in the Ank-Qz-Py, Qz-Au-Sul and Qz-Cal stages are -90.0 to $-86.8 \%$, -90.6 to $-89.6 \%$, and -97.2 to $-95.7 \%$, respectively, all of which plot within the range of igneous, metamorphic, and sedimentary rocks and meteoric water (Figure 12(a)). Accordingly, the $\delta^{18} \mathrm{O}_{\mathrm{V} \text {-SMOw }}$ values in each mineralization stage are $14.1-14.8 \%$, $16.8-17.3 \%$, and $14.2-14.6 \%$; they plot within the range of sedimentary rock and metamorphic rock (Figure 12(b)). In addition, the $\delta \mathrm{D}$ and $\delta^{18} \mathrm{O}_{\mathrm{H} 2 \mathrm{O}}$ values of the Ank-Qz-Py stage fluid plot far away from the metamorphic water but near magmatic water on the $\delta \mathrm{D}$ vs. $\delta^{18} \mathrm{O}_{\mathrm{H} 2 \mathrm{O}}$ diagram (Figure 13), indicating the low possibility of metamorphic origin of ore-forming fluid within Dagangou. The source of the ore-forming fluid of the Dagangou deposit seems very puzzling. Most researchers suggest that the origin of the primary oreforming fluids of the gold-polymetallic deposits in the EKO 


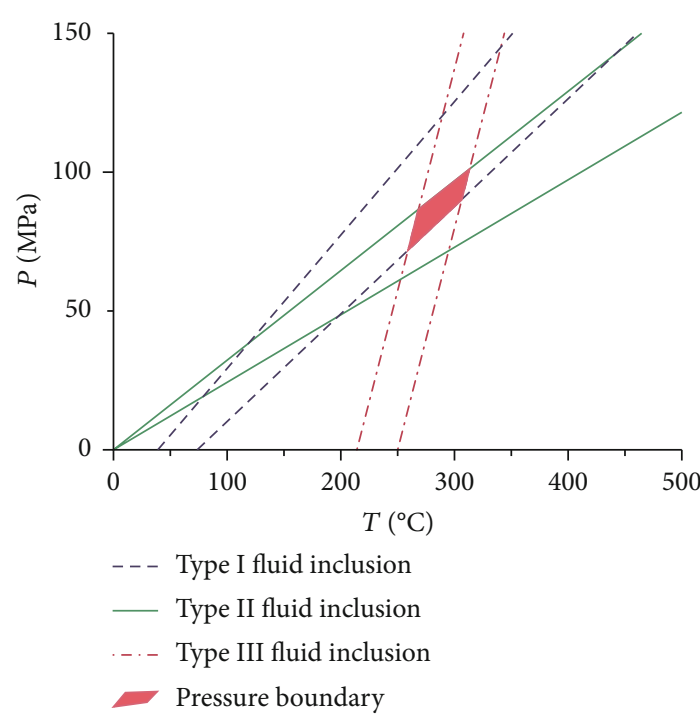

(a)

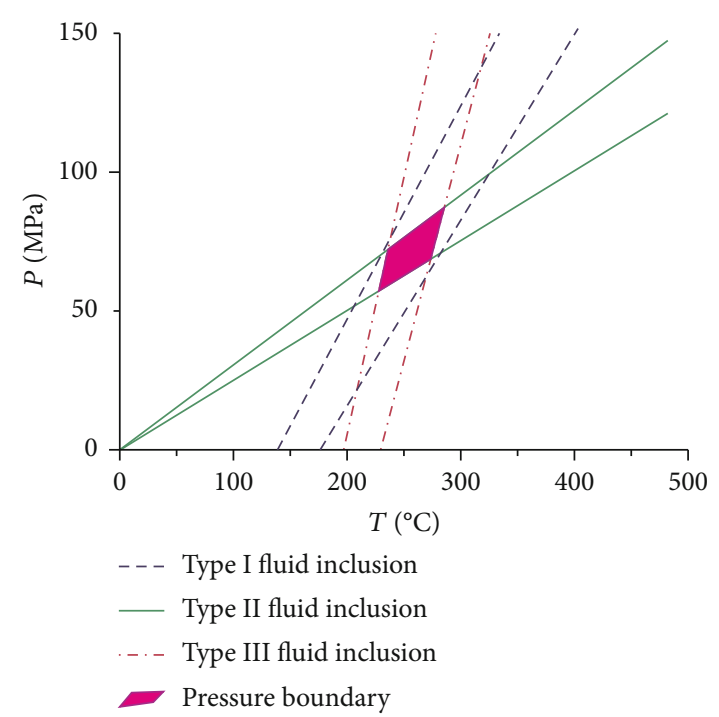

(b)

Figure 11: Isochore plots of fluid inclusions in Ank-Qz-Py (a) and Qz-Au-Sul (b) stages for the Dagangou Au-Ag-Cu-Sb deposit (modified after Bakker (2003) [47]).

is closely related to magmatic water, which generally belongs to the $\mathrm{NaCl}-\mathrm{H}_{2} \mathrm{O}-\mathrm{CO}_{2}$ system with minor $\mathrm{CH}_{4}$ and $\mathrm{N}_{2}[2,4-$ $6,17-22]$. Therefore, considering that the fluid was derived from depth $(>5 \mathrm{~km})$ and has a high salinity and high $\mathrm{CO}_{2}$ content, the primary ore-forming fluids of the Dagangou deposit likely originated from magmatic waters that mixed a few sedimentary waters rather than meteoric waters. The $\delta \mathrm{D}$ values in the Qz-Cal stage (-97.2 to $-95.7 \%$ ) decrease abruptly compared with those of the Ank-Qz-Py and QzAu-Sul stages (-90.6 to $-86.8 \%$ ), which suggests that an increasing amount of meteoric water was mixed, resulting in a reduction in the $\delta \mathrm{D}$ value as the mineralization depth became shallower in the Qz-Cal stage. Previous studies have shown that the $\delta \mathrm{D}$ and $\delta^{18} \mathrm{O}_{\mathrm{H} 2 \mathrm{O}}$ values of hydrothermal quartz within gold-polymetallic deposits of the EKO show a clear evolution in the $\delta \mathrm{D}$ vs. $\delta^{18} \mathrm{O}_{\mathrm{H} 2 \mathrm{O}}$ diagram (Figure 13 ). It has been suggested that the primary ore-forming fluids mainly involved magmatic fluids, whereas the Qz-Cal stage involved mixing with meteoric water [4-6, 17-22]. Most researchers suggest that mixing large amounts of meteoric water in Qz-Cal stage fluid is a common phenomenon for gold-polymetallic deposits in the EKO [4-6, 17-22]. Therefore, we suggest that the fluids in the Ank-Qz-Py and Qz$\mathrm{Au}$-Sul stages were most likely derived from magmatic water mixed with sedimentary water (e.g., Permian-Triassic sedimentary wall rock), whereas the fluid in the Qz-Cal stage was greatly diluted by meteoric water.

The evolution of ore-forming fluid in the Dagangou deposit can be divided into two stages. First, a significant phenomenon is that the $\mathrm{CO}_{2}$ content decreased abruptly and type IV FIs appeared in the Qz-Au-Sul stage compared with the Ank-Qz-Py stage. The fluids in the Qz-Au-Sul stage underwent a significant geological process that resulted in reduced $\mathrm{CO}_{2}$ and elevated salinity. Lu et al. [71] suggested that an $S$ (wt.\% $\mathrm{NaCl})-T_{\mathrm{h}}\left({ }^{\circ} \mathrm{C}\right)$ diagram plays a role in demonstrating the evolution of ore-forming fluids. The ore- forming fluids within the Dagangou deposit record an evolution from the Ank-Qz-Py stage to the Qz-Au-Sul stage, which is similar to trend 3 in Figure 14, where the salinity increases and the homogenization temperature rapidly decreases with the emergence of type IV FIs. The evolution of trend 3 is usually interpreted as fluid boiling [44], the Qz-Au-Sul stage fluid within the Dagangou deposit as well. This resulted in fluid phase separation and release of $\mathrm{CO}_{2}$ [71] and formed a great amount of FIs with highly varied $\mathrm{CO}_{2}$ and liquid phase contents [72]. The boiling event also increased the fluid salinity and caused physicochemical changes that led to sulfide formation and accelerated deposition of $\mathrm{Au}[72,73]$. In conclusion, the fluids in the Ank-QzPy stage that had moderate temperatures (trapping temperatures of $260-310^{\circ} \mathrm{C}$ ) and low-moderate salinities and were $\mathrm{CO}_{2}$-rich that evolved into Qz-Au-Sul stage $\mathrm{CO}_{2}$-bearing fluids with moderate temperatures (trapping temperatures of $230-280^{\circ} \mathrm{C}$ ) and high salinities due to fluid boiling.

Fluid boiling within the Dagangou deposit is also supported by $\mathrm{H}-\mathrm{O}$ isotopic variations. Wagner et al. [74] and Zhu [75] suggested that lighter isotopes are concentrated in vapour phases, which indicates that the residual fluid has higher $\delta^{18} \mathrm{O}$ values after boiling. In comparison, fluid mixing has the opposite effect on the oxygen isotope composition of the hydrothermal system, with $\delta^{18} \mathrm{O}$ values generally decreasing after mixing, although these values may increase during mixing at temperatures of approximately $250^{\circ} \mathrm{C}$ [74]. The $\delta^{18} \mathrm{O}$ values of the Dagangou ore-forming fluid vary from $6.7 \%$ to $7.4 \%$ during the Ank-Qz-Py stage, to 8.1-8.6\% during the Qz-Au-Sul stage, and to $3.9-4.3 \%$ during the Qz-Cal stage. This indicates that the primary fluid underwent boiling, which elevated the fluid $\delta^{18} \mathrm{O}$ values before this evolved fluid mixed with enough strata or meteoric waters, reducing the $\delta^{18} \mathrm{O}$ values of the Qz-Cal stage fluids. Of course, the fluid boiling in the Qz-Au-Sul stage is accompanied by the mixing of little sedimentary water and 


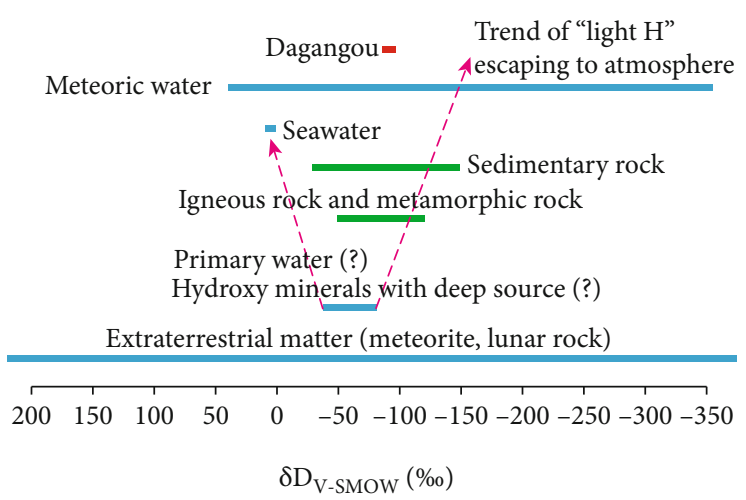

(a)

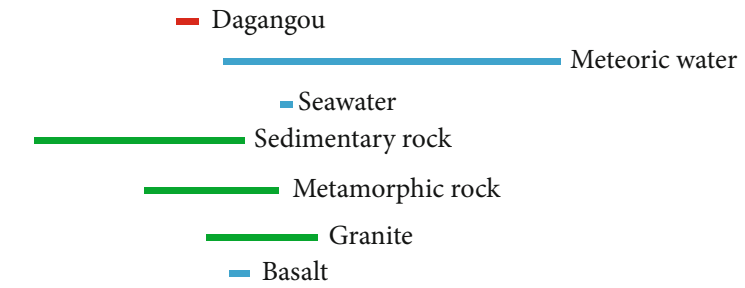

Extraterrestrial matter (meteorite, lunar rock)

\begin{tabular}{|c|c|c|c|c|c|c|c|c|c|c|}
\hline 40 & 30 & 20 & 10 & 0 & -10 & -20 & -30 & -40 & -50 & $-60-70$ \\
\hline
\end{tabular}

(b)

Figure 12: $\delta \mathrm{D}_{\mathrm{V} \text {-SMOW }}(\mathrm{a})$ and $\delta^{18} \mathrm{O}_{\mathrm{V} \text {-SMOW }}$ (b) comparison diagrams of the Dagangou ore-forming fluid with the nature systems showing the mixture origin (modified after Hoefs [51]).

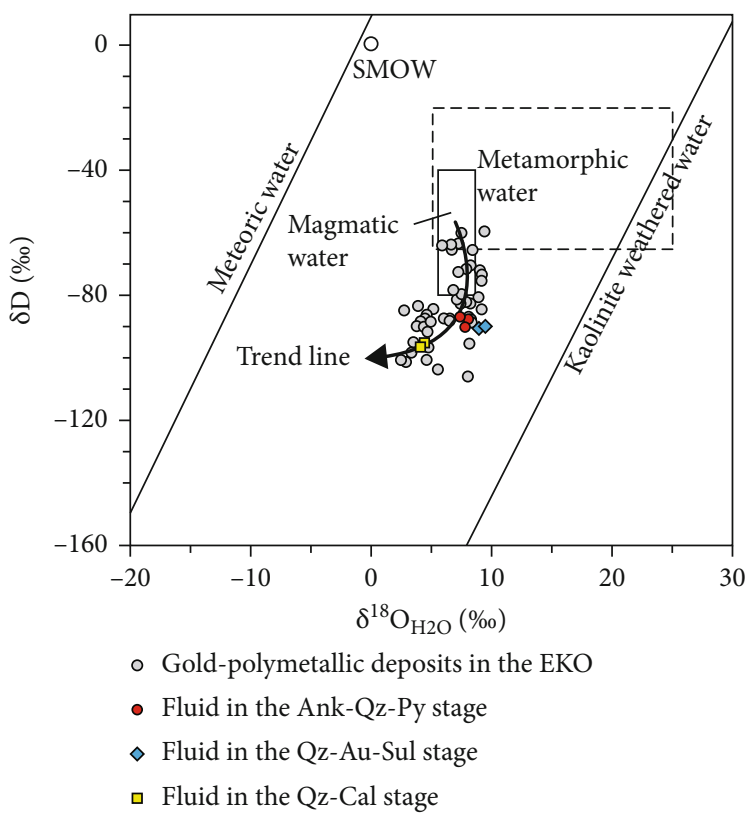

Figure 13: $\delta \mathrm{D}-\delta^{18} \mathrm{O}$ diagram of ore-forming fluid in the Dagangou Au-Ag-Cu-Sb deposit (modified after Clayton et al. [49]). Isotopic compositions of magmatic and metamorphic waters after Taylor (1974) and meteoric water line after Craig (1961). The data of gold-polymetallic deposit in EKO are collected from $[2,4-6,17-22]$.

fluid cooling. However, boiling is still the main mechanism for fluid evolution and metallic element deposition in the Dagangou deposit. Therefore, fluid boiling occurred in the Qz-Au-Sul stage due to a pressure reduction from $85 \mathrm{MPa}$ (average in the Ank-Qz-Py stage) to $70 \mathrm{MPa}$ (average in the Qz-Au-Sul stage), which was the most important mechanism of metallic element precipitation and enrichment in the Dagangou deposit. This led to the phase separation of fluid, a loss of $\mathrm{CO}_{2}$ due to escape, an increase in the salinity of the residual fluid, and the formation of immiscible inclusion assemblages and halite-bearing fluid inclusions in the Qz-Au-Sul stage, all of which indicate a system moving away from the original equilibrium, which resulted in the deposition of $\mathrm{Cu}, \mathrm{Sb}$, and $\mathrm{Au}$.

Second, the evolution of Qz-Au-Sul to Qz-Cal stage fluids is similar to trend 1 in Figure 14, which shows a rapid decrease in salinity and a less rapid decrease in homogenization temperature. This reflects a change from moderatetemperature, high-salinity, and $\mathrm{CO}_{2}$-bearing fluids in the Qz-Au-Sul stage to low-temperature, low-salinity, and $\mathrm{CO}_{2}$-free fluids in the Qz-Cal stage (Figures 7 and 8). It is suggested that the Qz-Au-Sul stage fluids mixed with lowtemperature and low-salinity meteoric water and formed liquid-rich inclusions (including vapour-liquid biphase and liquid monophase inclusions) and a minor number of $\mathrm{CO}_{2}$ bearing triphase inclusions [71, 76].

7.3. Mineralization Process. Phillips and Evans [77] suggested that ore-forming fluid carrying $\mathrm{Au}$ may contain $\mathrm{H}_{2} \mathrm{~S}$ and $\mathrm{CO}_{2}$, primarily because $\mathrm{H}_{2} \mathrm{~S}$ can complex with $\mathrm{Au}$ to form Au-S complexes and $\mathrm{CO}_{2}$ plays an important role in transporting Au. $\mathrm{CO}_{2}$ is a weak acid that can adjust the $\mathrm{pH}$ value 


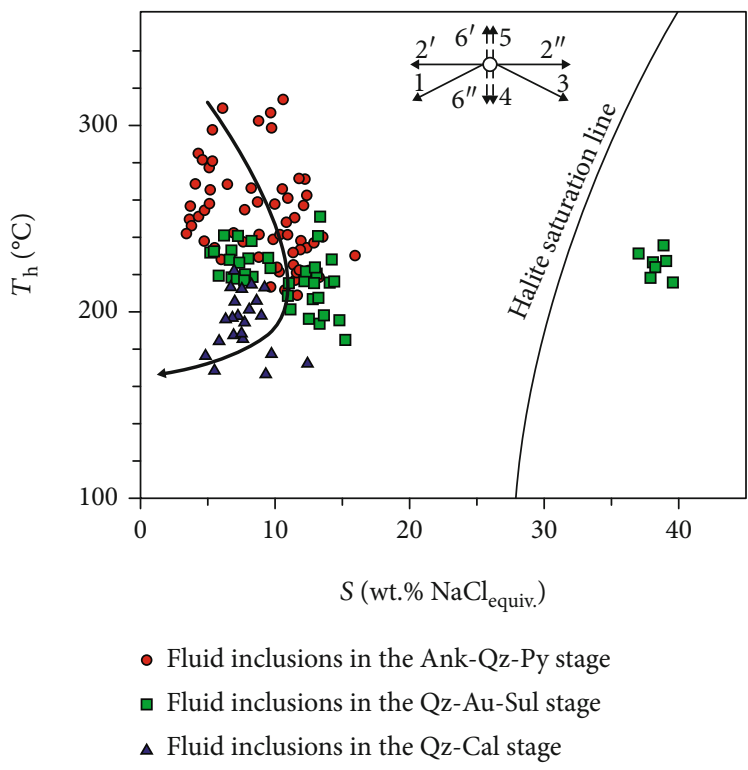

FIgURE 14: Bivariate diagram of homogenization temperature and salinity in the Dagangou Au-Ag-Cu-Sb deposit (modified from Li et al. [76]). 1: mixing with colder and lower-salinity fluids; $2^{\prime}$ : mixing with lower-salinity and isothermal fluids; $2^{\prime \prime}$ : Mixing with higher-salinity and isothermal fluids; 3: fluid boiling; 4: fluid cooling; 5: leaking of fluid inclusions; $6^{\prime}, 6^{\prime \prime}$ : neck down of fluid inclusions.

of the fluid to keep it within the stable existence range of $\mathrm{Au}-\mathrm{S}$ complexes, thus increasing the solubility of gold [77]. Gold is mostly transported in hydrothermal solutions as gold bisulfide $\left[\mathrm{Au}(\mathrm{HS})^{0}, \mathrm{HAu}(\mathrm{HS})_{2}{ }^{0}\right.$, and $\left.\mathrm{Au}(\mathrm{HS})_{2}\right]$ and gold chloride $\left[\mathrm{AuCl}_{2}^{-}, \mathrm{AuCl}^{0}\right.$, and $\left.\mathrm{AuCl}(\mathrm{OH})^{-}\right]$complexes, and the deposition of $\mathrm{Au}$ from hydrothermal fluids is associated with a decrease in the activity of $\mathrm{Au}(\mathrm{HS})_{2}{ }^{-}$or $\mathrm{Au}(\mathrm{HS})^{0}$ [78-80]. Cooling, boiling, attenuation, changes in $\mathrm{pH}$, and sulfide deposition can all reduce the $\mathrm{H}_{2} \mathrm{~S}$ content to precipitate Au. The solubility of $\mathrm{Au}$ in a $\mathrm{H}_{2} \mathrm{~S}-\mathrm{HS}$ to $-\mathrm{SO}_{4}{ }^{2-}$ system reaches a maximum value in the reduced sulfur field at temperatures $>400^{\circ} \mathrm{C}$ [81]. Oxidation of this fluid can cause the dissociation of Au-S complexes to precipitate $\mathrm{Au}$. The reduction in $\mathrm{CH}_{4}$ vapour during the Ank-Qz-Py stage of mineralization can also cause $\mathrm{Au}$ deposition, as $\mathrm{HS}^{-}$can easily react with $\mathrm{H}^{+}$to form $\mathrm{H}_{2} \mathrm{~S}$, thereby reducing the stability of $\mathrm{Au}(\mathrm{HS})_{2}{ }^{-}$and resulting in the deposition of $\mathrm{Au}$ from the sulfide solution. The reaction between $\mathrm{HS}^{-}$and $\mathrm{H}^{+}$also consumes the latter, leading to the loss of $\mathrm{CO}_{2}$ and increasing the $\mathrm{pH}$ of the ore-forming fluid as a result of the following reaction:

$$
\mathrm{Au}(\mathrm{HS})_{2}^{-}+0.5 \mathrm{H}_{2} \mathrm{O} \Rightarrow \mathrm{Au}+2 \mathrm{HS}-+\mathrm{H}++0.25 \mathrm{O}_{2}
$$

This reaction produces $H^{+}$, and then stibnite precipitates as follows:

$$
\mathrm{HSb}_{2} \mathrm{~S}_{4}^{-}+\mathrm{H}^{+} \Rightarrow \mathrm{Sb}_{2} \mathrm{~S}_{3}+\mathrm{H}_{2} \mathrm{~S}
$$

In conclusion, it is suggested that the primary $\mathrm{H}_{2} \mathrm{O}-\mathrm{C}$ $\mathrm{O}_{2}-\mathrm{NaCl}$ fluid underwent a significant boiling event, which caused immiscibility and the loss of $\mathrm{CO}_{2}[53,71,73]$, leading to $\mathrm{Au}$ and stibnite precipitation in the massive and vein-type ores.
7.4. Ore Genesis. Generally, the ore-forming fluids associated with hydrothermal vein-type gold-polymetallic deposits have low salinities (generally $<10 \%$ ), contain high concentrations (5-30 mol\% or higher) of $\mathrm{CO}_{2}+\mathrm{CH}_{4}$, and contain immiscible $\mathrm{H}_{2} \mathrm{O}$ and $\mathrm{CO}_{2}$, although some of the fluids can have salinities of $10-20 \%$ or higher [82]. Similar to the Dagangou $\mathrm{Au}-\mathrm{Ag}-\mathrm{Cu}-\mathrm{Sb}$ deposit, the salinity of the fluid can be as high as $40 \mathrm{wt} . \% \mathrm{NaCl}_{\text {equiv }}$. Mineral-bearing FIs (such as the type IV FIs in the Dagangou deposit) have been described from some hydrothermal gold-polymetallic deposits, including the Wiluna deposit in Australia [83] and the Lengshuibeigou $\mathrm{Pb}-\mathrm{Zn}$ deposit in Henan Province, China [84]. These highsalinity or mineral-bearing FIs were trapped during the main or late stage but were generated by $\mathrm{CO}_{2}-\mathrm{H}_{2} \mathrm{O}$ fluid boiling during the early or main stage [43-84].

The primary $\mathrm{H}_{2} \mathrm{O}-\mathrm{NaCl}-\mathrm{CO}_{2}$ fluid in the Ank-Qz-Py stage was mainly derived from magmatic water, which mixed with minor crustal water and contained significant amounts of $\mathrm{CO}_{2}$ with minor $\mathrm{CH}_{4}, \mathrm{~N}_{2}$, and $\mathrm{C}_{2} \mathrm{H}_{6}$. It is characterized by a moderate-high temperature and a low-moderate salinity and density, while the salinity in the Qz-Au-Sul stage can reach 40 wt.\% $\mathrm{NaCl}_{\text {equiv. }}$ due to fluid boiling. Then, fluid boiling and immiscibility took place in the Qz-Au-Sul stage, which led to phase separation, a rapid loss of $\mathrm{CO}_{2}$, an increase in the salinity of the residual fluid, and the formation of halite-bearing inclusions in the Qz-Au-Sul stage. This indicates that a system moving away from equilibrium would have resulted in the deposition of $\mathrm{Cu}, \mathrm{Sb}$, and $\mathrm{Au}$. Finally, the fluids in the Qz-Cal stage were mixed with meteoric water, which significantly reduced the fluid temperature and salinity. The evolution characteristics of the ore-forming fluids in the Dagangou deposit were consistent with the fluid system and evolution regularity of orogenic deposits [72, 82], especially the hydrothermal vein-type gold-polymetallic deposits in the EKO, such as Dachang, Wulonggou, Xintuo, 
Asiha, Guoluolongwa, and Annage. They are all identified as orogenic gold deposits with the same or similar geological setting, metallogenic age, and fluid composition and evolution $[1-7,15-26]$.

Finally, the Au-Ag-Cu-Sb ore bodies within the Dagangou deposit are hosted by a nearly E-W-trending fault zone within Permian-Triassic strata with no selectivity to the surrounding rock. All of them are structurally controlled by a series of nearly E-W-trending faults in the ductile shear zone, which shows an epigenetic deposit. The ore is produced in the form of sulfide-rich altered rocks or a small amount of quartz veins, both hosted in the fracture zone within the shear zone. The shear zone determines the shape, occurrence, scale, and placement of the ore bodies, and sulfides are mainly hosted in the fragmented rocks in the shear zone, producing veins of different scales, such as microveins, veinlets, or veins. Meanwhile, the wall rock around the shear zone is also altered to different degrees due to the hydrothermal fluid but weak mineralization. The ore-forming element assemblage ( $\mathrm{Au}-\mathrm{Ag}-\mathrm{Cu}-\mathrm{Sb})$ is close to the $\mathrm{Au}-\mathrm{Sb}$ of the epigenetic gold deposit, and the alteration mineral assemblage shows that the ore-bearing hydrothermal fluid is rich in $\mathrm{CO}_{2}, \mathrm{~S}$, and $\mathrm{K}$. The alteration of the surrounding rock is linear and mainly spreads along the fault zone, with transverse zoning of tens of metres, but vertical zoning is not obvious. The Dagangou $\mathrm{Au}-\mathrm{Ag}-\mathrm{Cu}-\mathrm{Sb}$ deposit, therefore, most likely represents an orogenic goldpolymetallic deposit with a mesozonal depth of $5.9-7.5 \mathrm{~km}$.

\section{Conclusions}

(i) Four types of primary FIs are recognized within the Dagangou deposit: pure $\mathrm{CO}_{2}, \mathrm{CO}_{2}$-bearing triphase, vapour-liquid biphase, and halite-bearing triphase FIs, and various FIAs are identified through petrographic observations in each stage. The FIs homogenized at $167.3-313.4^{\circ} \mathrm{C}$ with salinities of $3.4-39.5$ wt.\% $\mathrm{NaCl}_{\text {equiv. }}$ and densities of $0.60-1.08 \mathrm{~g} / \mathrm{cm}^{3}$. Their vapour phases are dominated by $\mathrm{H}_{2} \mathrm{O}$ and $\mathrm{CO}_{2}$ with minor $\mathrm{N}_{2}, \mathrm{CH}_{4}$, and $\mathrm{C}_{2} \mathrm{H}_{6}$

(ii) The sulfides have $\delta^{34} \mathrm{~S}$ values of -1.4-5.1\%o, indicating a predominant source of sedimentary sulfur with minor magmatic sulfur. The $\mathrm{H}-\mathrm{O}$ isotopes $\left(\delta \mathrm{D}=-90.0\right.$ to $-86.8 \%$, $\delta^{18} \mathrm{O}_{\mathrm{H} 2 \mathrm{O}}=6.7-7.4 \%$ ) $)$ suggest that the primary fluid was mainly derived from magmatic water with minor sedimentary water and was greatly diluted by meteoric water in the Qz-Cal stage

(iii) $\mathrm{Au}, \mathrm{Ag}, \mathrm{Cu}$, and $\mathrm{Sb}$ were deposited as a result of fluid boiling in the Qz-Au-Sul stage due to a pressure reduction from $85 \mathrm{MPa}$ to $70 \mathrm{MPa}$. This led to the phase separation of fluid, loss of $\mathrm{CO}_{2}$ due to escape, increase in residual fluid salinity, and formation of immiscible FIAs and halite-bearing FIs in the QzAu-Sul stage, all of which are indicative of a system moving away from primary equilibrium

(iv) The Dagangou deposit is an orogenic goldpolymetallic deposit with a mesozonal depth of $5.9-7.5 \mathrm{~km}$

\section{Data Availability}

The data used to support the findings of this study are included within the article.

\section{Conflicts of Interest}

The authors declare that they have no conflicts of interest.

\section{Acknowledgments}

We would like to thank the Geological Fluid Laboratory of Jilin University and Analytical Laboratory of Beijing Research Institute of Uranium Geology for helping in the analyses. We also thank Xi'an Institute of Geological and Mineral Exploration and the No.5 Institute of Geology and Minerals Exploration of Qinghai Province, for their assistance during field investigation. This research was financially supported by the Scientific Research Fund of Postdoctoral Fellow in Yunnan University (C176220200), Joint Foundation Project between Yunnan Science and Technology Department and Yunnan University (2019FY003011), and National Natural Science Foundation of China (41872089).

\section{References}

[1] D.-Q. Zhang, H. Zhang, C.-Y. Feng, H.-Q. She, J.-W. Li, and D.-X. Li, "Fluid inclusions in orogenic gold deposits in the northern Qaidam magin-East Kunlun Region," Geology China, vol. 34, pp. 843-854, 2007.

[2] C.-Y. Feng, D.-Q. Zhang, F.-C. Wang, D.-X. Li, and H. Q. She, "Geochemical characteristics of ore-forming fluids from the orogenic $\mathrm{Au}$ (and $\mathrm{Sb}$ ) deposits in the eastern Kunlun area, Qinghai province," Acta Petrologica Sinica, vol. 20, pp. 949960, 2004.

[3] C.-S. Zhao, J.-W. Zhao, F.-Y. Sun, and X.-Q. Li, "A discussion on geological characteristics and genesis of Dachang gold deposit in Qinghai Province," Mineral Deposits, vol. 28, pp. 345-356, 2009.

[4] B.-L. Li, X. Shen, G.-J. Chen, Y.-Q. Yang, and Y.-S. Li, "Geochemical features of ore-forming fluids and metallogenesis of vein I in Asiha gold ore deposit, Eastern Kunlun, Qinghai Province," Journal of Jilin University (Earth Science Edition), vol. 42, p. 1676, 2012.

[5] Q.-F. Ding, S.-K. Jin, G. Wang, and B.-L. Zhang, "Ore-forming fluid of the Guoluolongwa gold deposit in Dulan County, Qinghai Province," Journal of Jilin University (Earth Science Edition), vol. 43, pp. 415-426, 2013.

[6] Q.-F. Ding, G. Wang, F.-Y. Sun, B.-L. Zhang, and S.-K. Jin, "Ore-forming fluid evolution of Dachang gold deposit in Qumalai County, Qinghai Province: evidence from fluid inclusion study and arsenopyrite geothermometer," Acta Petrologica Sinica, vol. 26, pp. 3709-3719, 2010.

[7] L. Kou and S. Zhang, "Chronological study of tectonism and mineralization in Wulonggou gold deposit, Eastern Kunlun," Acta Geological Sinica, vol. 88, no. s2, pp. 738-739, 2014.

[8] X.-H. Deng, Y.-J. Chen, L. Bagas et al., "Cassiterite U-Pb geochronology of the Kekekaerde W-Sn deposit in the Baiganhu ore field, East Kunlun Orogen, NW China: timing and tectonic setting of mineralization," Ore Geology Reviews, vol. 100, pp. 534-544, 2018. 
[9] M. Yu, C.-Y. Feng, J.-W. Mao, Y.-M. Zhao, B. Li, and Y.F. Zhu, "Multistage skarn-related tourmaline from the Galinge deposit, Qiman Tagh, Western China: a fluid evolution perspective," The Canadian Mineralogist, vol. 55, no. 1, pp. 319, 2017.

[10] M. Huang, J. Lai, and Q. Mo, "Fluid inclusions and metallization of the Kendekeke polymetallic deposit in Qinghai Province, China," Acta Geological Sinica, vol. 88, no. 2, pp. 570583, 2014.

[11] J.-M. Yan, F.-Y. Sun, B.-L. Li et al., "Geochronological, geochemical, and mineralogical characteristics of the Akechukesai-I mafic-ultramafic complex in the eastern Kunlun area of the northern Tibet Plateau, west China: insights into ore potential," Ore Geology Reviews, vol. 121, pp. 1-13, 2020.

[12] Y.-X. Han, Y.-H. Liu, and W.-Y. Li, "Mineralogy of nickel and cobalt minerals in Xiarihamu nickel-cobalt deposit, East Kunlun Orogen, China," Frontiers in Earth Science, vol. 8, article 597469, 2020.

[13] L. Li, D.-X. Zhang, S.-C. Tan et al., "The parental magma composition, crustal contamination process, and metallogenesis of the Shitoukengde Ni-Cu sulfide deposit in the Eastern Kunlun Orogenic Belt, NW China," Resource Geology, vol. 1-24, 2021.

[14] C.-S. Tian, Research on Gold Mineralization and Metallogenic Prognosis in Wulonggou Ore Concentration Areas of East Kunlun Middle Part, [Ph. D Thesis], China University of Geosciences (Beijing), Beijing, China, 2012.

[15] G.-J. Chen, Metallogenesis of Gold Deposits in Gouli Regional and Peripheral Area of East Kunlun, Qinghai Province, [Ph. $D$ Thesis], Jilin University, Changchun, China, 2014.

[16] J. LAI, P. JU, and Y. CAO, "Polygenetic compound mineralization of Guoluolongwa Gold Field, Qinghai," Acta Geologica Sinica, vol. 88, no. s2, pp. 743-744, 2014.

[17] Y.-T. Zhang, Research on Metallogenesis of Gold Deposits in the Wulongou Ore Concentration Area, Central Segment of the East Kunlun Mountains, Qinghai Province, [Ph. D Thesis], Jilin University, Changchun, China, 2018.

[18] J.-W. Zhao, Study on Orogenic Gold Metallogenic Series in Eastern Kunlun Orogenic Belt, Qinghai Province, [Ph. D Thesis], Jilin University, Changchun, China, 2008.

[19] X. Shen, Study on Geological Characteristics and Genesis of Asiha Gold Deposit, East Kunlun, Qinghai Province, [M.S. Thesis], Jilin University, Changchun, China, 2012.

[20] W.-H. Yue, Study on the Geology, Geochemistry and Metallogenic Mechanism of Typical Deposits in the Gouli Gold Concentration Area, East Segment of Eastern Kunlun, [Ph. D. Thesis], Kunming University of Science and Technology, Kunming, China, 2013.

[21] B.-L. Chen, Y. Wang, Y. Han, and J.-L. Chen, "Metallogenic age of Yanjingou gold deposit in Wulonggou gold orefield, eastern Kunlun Mountains," Mineral Deposits, vol. 38, pp. 541-556, 2019.

[22] L. Cheng, Study on Geological and Geochemical Characteristics Genesis of Hongqigou Gold Deposit, Wulonggou Ore Concentration Area, East Kunlun, Qinghai Province, [M.S. Thesis], Jilin University, Changchun, China, 2020.

[23] F. Zhou, Research on Fluid Inclusions of Guoluolongwa Gold Area in Qinghai Province, [M.S. Thesis], Central South University, Changsha, China, 2010.

[24] G. Wang, Study on Geological Characteristics and Genesis of Guoluolongwa Gold Deposit in Qinghai Province, [M.S. Thesis], Jilin University, Changchun, China, 2012.
[25] J.-J. Tao, Characteristics of Fluid Inclusions and Genesis of Annage Gold Deposit, Qinghai Province, [M.S. Thesis], Central South University, Changsha, China, 2014.

[26] J.-Q. Lai, P.-J. Ju, J.-J. Tao, B.-R. Yang, and X.-Y. Wang, "Characteristics of fluid inclusions and metallogenesis of Annage gold deposit in Qinghai Province, China," Open Journal of Geology, vol. 5, pp. 580-794, 2015.

[27] W.-M. Yuan, S.-C. Wang, and L.-F. Wang, "Metallogenic thermal history of the Wulonggou gold deposits in East Kunlun Mountains in the light of fission track thermochronology," Acta Geoscientia Sinica, vol. 21, pp. 389-395, 2000.

[28] W.-M. Yuan, X.-X. Mo, A.-K. Zhang et al., "Fission track thermochronology evidence for multiple periods of mineralization in the Wulonggou gold deposits, Eastern Kunlun Mountains, Qinghai Province," Journal of Earth Science, vol. 24, no. 4, pp. 471-478, 2013.

[29] D.-Q. Zhang, X.-Y. Dang, H.-Q. She, D.-X. Li, C.-Y. Feng, and J.-W. Li, "Ar-Ar dating of orogenic gold deposits in northern margin of Qaidam and East Kunlun Mountains and its geological significance," Mineral Deposits, vol. 24, pp. 87-98, 2005.

[30] F. Bian, Chronology Study and Discussion on Genetic Type of Dachang Gold Deposit in Qinghai Province, [M.S. Thesis], Northwestern University, Xi'an, China, 2012.

[31] J.-Y. Zhang, C.-Q. Ma, J.-W. Li, and Y.-M. Pan, "A possible genetic relationship between orogenic gold mineralization and post- collisional magmatism in the eastern Kunlun Orogen, western China," Ore Geology Reviews, vol. 81, pp. 342-357, 2017.

[32] K. Zhang, R.-T. Gou, S.-L. Liu et al., "Characteristics and significance of the copper-gold-antimony deposits in Dagangaou area, East Kunlun," Journal of Geomechanics, vol. 18, pp. 401409, 2012, (In Chinese).

[33] Z.-Q. Xu, J.-S. Yang, and H.-B. Li, Terrane Amalgamation, Collision and Uplift in the Qinghai-Tibet Plateau, Geological Publishing House, Beijing, China, 2007.

[34] F.-Y. Sun, G.-H. Chen, X.-G. Chi et al., Report of Metallogenic Regularity and Prospecting Direction for the Eastern Kunlun Metallogenic Belt in Xinjiang-Qinghai, Geological Survey of Jilin University, Changchun, China, 2003.

[35] F.-Y. Sun, B.-L. Li, Q.-F. Ding et al., Report of Significant Exploration Problem for Eastern Kunlun Metallogenic Belt in Qinghai Province, Geological Survey of Jilin University, Changchun, China, 2009.

[36] Q.-R. Wei, D.-W. Li, and G.-C. Wang, "Geochemical characteristics and tectonic setting of volcanic rocks from the Wanbaogou Group in East Kunlun Orogenic Belt," Journal of Mineral Petrology, vol. 27, pp. 97-106, 2007.

[37] H. Wang, Geochemical Characteristics of Wanbaogou GroupComplex Volcanic Rocks from Gouli Area, Qinghai, and Their Significance, [Ph. D. Thesis], Chang'an University, Xi'an, China, 2009.

[38] C. Yuan, M.-F. Zhou, M. Sun et al., "Triassic granitoids in the eastern Songpan Ganzi Fold Belt, SW China: magmatic response to geodynamics of the deep lithosphere," Earth and Planetary Science Letters, vol. 290, no. 3-4, pp. 481-492, 2010.

[39] K. Zhang, Preliminary Report of Dagangou Cu-Au-Ag-Cu-Sb Polymetallic Deposit in Golmud City, Qinghai Province, Xi'an Institute of Geological and Mineral Exploration, Shannxi Geology and Mineral Bureau, Xi'an, China, 2013.

[40] D. L. Whitney and B. W. Evans, "Abbreviations for names of rock-forming minerals," American Mineralogist, vol. 95, no. 1, pp. 185-187, 2010. 
[41] R. H. Goldstein and T. J. Reynolds, "Systematics of fluid inclusions in diagenetic minerals," SEPM (Society for Sedimentary Geology) Short Course, vol. 31, pp. 1-199, 1994.

[42] R. J. Bodnar, "Introduction to fluid inclusions," in Fluid Inclusions-Analysis and Interpretation, I. Samson, A. Anderson, and D. Marshall, Eds., vol. 32 of Short Course Series, , pp. 1-8, Mineralogical Association of Canada, 2003.

[43] Q.-H. Shu, Z.-S. Chang, and J. Mavrogenes, "Fluid compositions reveal fluid nature, metal deposition mechanisms, and mineralization potential: an example at the Haobugao $\mathrm{Zn}-\mathrm{Pb}$ skarn, China," Geology, vol. 49, no. 4, pp. 473-477, 2020.

[44] T. J. Shepherd, A. H. Rankin, and D. H. M. Alderton, A Practical Guide to Fluid Inclusion Studies, Blackie: Chapman and Hall, 1985.

[45] E. Roedder and R. J. Bodnar, "Geologic pressure determinations from fluid inclusion studies," Annual Review of Earth and Planetary Sciences, vol. 8, no. 1, pp. 263-301, 1980.

[46] H.-R. Fan, M.-G. Zhai, Y.-H. Xie, and J.-H. Yang, "Ore-forming fluids associated with granite-hosted gold mineralization at the Sanshandao deposit, Jiaodong gold province, China," Mineralium Deposita, vol. 38, no. 6, pp. 739-750, 2003.

[47] R. J. Bakker, "Package_FLUIDS_ 1\. Computer programs for analysis of fluid inclusion data and for modelling bulk fluid properties," Chemical Geology, vol. 194, no. 1-3, pp. 3-23, 2003.

[48] H.-B. Liu, G.-S. Jin, J.-J. Li et al., "Determination of stable isotope composition in uranium geological samples," World Nuclear Geoscience, vol. 30, pp. 174-179, 2013.

[49] R. N. Clayton, J. R. O'Neil, and T. K. Mayeda, "Oxygen isotope exchange between quartz and water," Journal of Geophysical Research, vol. 77, no. 17, pp. 3057-3067, 1972.

[50] M. Steele-Maclnnis, P. Lecumberri-Sanchez, and R. J. Bodnar, "HokieFlincs_H2O-NaCl: a Microsoft Excel spreadsheet for interpreting microthermometric data from fluid inclusions based on the PVTX properties of $\mathrm{H}_{2} \mathrm{O}-\mathrm{NaCl}$," Computers \& Geosciences, vol. 49, pp. 334-337, 2012.

[51] J. Hoefs, Stable Isotope Geochemistry, Springer Verlag, BerlinHeidelberg-New York, 1973.

[52] C. Ramboz, M. Pichavant, and A. Weisbrod, "Fluid immiscibility in natural processes: use and misuse of fluid inclusion data: II. Interpretation of fluid inclusion data in terms of immiscibility," Chemical Geology, vol. 37, no. 1-2, pp. 29-48, 1982.

[53] H.-Z. Lu, "Fluid inclusion studies of some Archean gold deposits," Acta Mineralogica Sinica, vol. 11, pp. 289-297, 1991.

[54] V. S. Kamenetsky and M. B. Kamenetsky, "Magmatic fluids immiscible with silicate melts: examples from inclusions in phenocrysts and glasses and magma evolution and transport," Geofluids, vol. 10, 311 pages, 2010.

[55] G.-X. Chi and H.-Z. Lu, "Validation and representation of fluid inclusion microthermometric data using the fluid inclusion assemblage (FIA) concept," Acta Petrologica Sinica, vol. 24, pp. 1945-1953, 2008.

[56] H.-Z. Lu, "Role of CO2 fluid in the formation of gold deposits: fluid inclusion evidence," Geochimica, vol. 37, pp. 321-328, 2008.

[57] H.-Z. Lu, "Fluids immiscibility and fluid inclusions," Acta Geologica Sinica, vol. 27, pp. 1253-1261, 2011.

[58] H.-Z. Lu, G.-X. Chi, X.-Q. Zhu, J. Guha, G. Archambault, and Z.-G. Wang, "Geological characteristics and ore forming fluids of orogenic gold deposits," Geotectonica et Metallogenia, vol. 42, pp. 244-265, 2018.

[59] Y.-G. Zhang and J. D. Frantz, "Experimental determination of the compositional limits of immiscibility in the system $\mathrm{CaCl}_{2}$ $\mathrm{H}_{2} \mathrm{O} \mathrm{CO}$ at high temperatures and pressures using synthetic fluid inclusions," Chemical Geology, vol. 74, no. 3-4, pp. 289308, 1989.

[60] G.-X. Chi and H.-Z. Lu, "Characteristics of fluid phase separation fields in a depth-temperature coordinate with emphasis on their significance in localization of hydrothermal deposits," Acta Mineralogica Sinica, vol. 11, pp. 355-362, 1991.

[61] J. D. Frantz, R. K. Popp, and T. C. Hoering, "The compositional limits of fluid immiscibility fluid inclusions in conjunction with mass spectrometry," Chemical Geology, vol. 98, pp. 23-255, 1992.

[62] J.-Y. Ding and P. Ni, "Synthetic fluid inclusions in $\mathrm{NaCl}-$ $\mathrm{CaCl}_{2}-\mathrm{H}_{2} \mathrm{O}$ system and features under cooling," Acta Petrologica Sinica, vol. 23, pp. 2039-2044, 2007.

[63] W.-H. Zhang and Z.-Y. Chen, Geology of Fluid Inclusions, China University of Geosciences Press, Wuhan, China, 1993.

[64] F. Robert and W. C. Kelly, "Ore-forming fluids in Archean gold-bearing quartz veins at the Sigma mine, Abitibi greenstone belt, Quebec, Canada," Economic Geology, vol. 82, no. 6, pp. 1464-1482, 1987.

[65] M. S. Ibrahim and T. K. Kyser, "Fluid inclusion and isotope systematics of the high-temperature Proterozoic Star Lake Lode gold deposit, Northern Saskatchewan, Canada," Economic Geology, vol. 86, no. 7, pp. 1468-1490, 1991.

[66] P. E. Brown and S. G. Hagemann, "MacFlinCor and its application to fluids in Archean lode-gold deposits," Geochimica et Cosmochimica Acta, vol. 59, no. 19, pp. 3943-3952, 1995.

[67] B. Liu and K. Shen, Thermodynamics of Fluid Inclusion, Geological Publishing House, Beijing, 1999.

[68] H. Craig, "Isotopic variations in meteoric waters," Science, vol. 133, no. 3465, pp. 1702-1703, 1961.

[69] H. P. Taylor, "The application of oxygen and hydrogen isotope studies to problems of hydrothermal alteration and ore deposition," Economic Geology, vol. 69, no. 6, pp. 843-883, 1974.

[70] F.-Y. Sun, W. Jin, B.-L. Li, and X.-L. Peng, "Considerations on the mineralizing depth of hydrothermal lode gold deposits," Journal of Changchun University of Science and Technology, vol. 30, pp. 27-30, 2000.

[71] H.-Z. Lu, H.-R. Fan, P. Ni, G.-X. Ou, K. Shen, and W. H. Zhang, Fluid Inclusion, Science Press, Beijing, China, 2004.

[72] J.-P. Qi, Y.-J. Chen, P. Ni et al., "Fluid inclusion constrains on the origin of the Lengshuibeigou $\mathrm{Pb}-\mathrm{Zn}-\mathrm{Ag}$ deposit, Henan Province," Acta Petrologica Sinica, vol. 23, pp. 2119-2130, 2007.

[73] F.-F. Hu, H.-R. Fan, H. Yu, Z.-H. Liu, L.-F. Song, and C.-W. Jin, "Fluid inclusions in the Sanjia lode gold deposit, Jiaodong peninsula of eastern China," Acta Petrologica Sinica, vol. 24, pp. 2037-2044, 2008.

[74] T. Wagner, M. J. Mlynarczyk, A. E. Williams-Jones, and A. J. Boyce, "Stable isotope constraints on ore formation at the San Rafael tin-copper deposit, Southeast Peru," Economic Geology, vol. 104, no. 2, pp. 223-248, 2009.

[75] Y.-F. Zhu, Introduction to Geochemistry of Mineral Deposit, Peking University Press, Beijing, China, 2012.

[76] L. Li, F.-Y. Sun, B.-L. Li, Y. Qian, and Q.-L. Xu, "Ore-forming fluid features and genesis of Shabaosi gold deposit in Mohe 
County, Heilongjiang Province," Earth Science-Journal of China University of Geosciences, vol. 40, pp. 1163-1176, 2015.

[77] G. N. Phillips and K. A. Evans, "Role of $\mathrm{CO}_{2}$ in the formation of gold deposits," Nature, vol. 429, no. 6994, pp. 860-863, 2004.

[78] K. Hayashi and H. Ohmoto, "Solubility of gold in $\mathrm{NaCl}$-and $\mathrm{H}_{2}$ S-bearing aqueous solutions at $250-350^{\circ} \mathrm{C}$," Geochimica et Cosmochimica Acta, vol. 55, no. 8, pp. 2111-2126, 1991.

[79] T. M. Seward, "The hydrothermal geochemistry of gold," in Gold Metallogeny and Exploration, R. P. Foster, Ed., pp. 3762, Chapman \& Hall, London, 1991.

[80] A. V. Zotov, N. N. Baranova, T. G. Dar'Yina, and L. M. Bannykhl, "The solubility of gold in aqueous chloride fluids at 350-500 ${ }^{\circ} \mathrm{C}$ and 500-1500 Atm: thermodynamic parameters of AuCl-2(sol) up to $750^{\circ} \mathrm{C}$ and $500 \mathrm{Atm}$," Geochemistry International, vol. 28, pp. 63-71, 1991.

[81] L. G. Benning and T. M. Seward, "Hydrosulphide complexing of $\mathrm{Au}(\mathrm{I})$ in hydrothermal solutions from $150-400^{\circ} \mathrm{C}$ and $500-$ 1500 bar," Geochimica et Cosmochimica Acta, vol. 60, no. 11, pp. 1849-1871, 1996.

[82] Y.-J. Chen, P. Ni, H.-R. Fan, F. Pirajno, Y. Lai, and W.-C. Su, "Diagnostic fluid inclusions of different types hydrothermal gold deposits," Acta Petrologica Sinica, vol. 23, pp. 20852108, 2007.

[83] S. G. Hagemann and V. Luders, "P-T-X conditions of hydrothermal fluids and precipitation mechanism of stibnite-gold mineralization at the Wiluna lode-gold deposits, Western Australia: conventional and infrared microthermometric constraints," Mineralium Deposita, vol. 38, no. 8, pp. 936-952, 2003.

[84] H.-Y. Chen, Y.-J. Chen, P. Ni, and Z.-J. Zhang, "Fluid inclusion study of the Sawayardun Au deposit in southern Tianshan, China: implication for ore genesis and exploration," Journal of Mineralogy and Petrology, vol. 24, pp. 46-54, 2004. 